Studia UBB Digitalia, Volume 64 (LXIV) 2019, December, Issue 2

Published Online: 2020-12-05

DOI:10.24193/subbdigitalia.2019.2.01

\title{
Digital Framework for the History of the Austrian Military Border in Transylvania
}

\author{
Sandra Hirsch, Csaba Horváth, Angela Lumezeanu, \\ Vlad Popovici \\ Babeș-Bolyai University Cluj-Napoca
}

\begin{abstract}
The study provides the documentation for the first public version of the database Digital Framework for the History of the Austrian Military Border in Transylvania by means of a detailed description and user manual. It includes: a short overview of the historical context of the establishment of the Austrian military border in this province, references to the international and Romanian state of the art, the detailing of primary sources issued by the military environment and starting from which the database was built and the main principles of construction and operation of the latter. The information in the database is extracted from the records of the military and administrative personnel of the Transylvanian border regiments between 1763 and 1850, including monthly staff records, information on salaries, enrollments, transfers, desertions, medical certificates, etc. The lists of conduct of the officers should also be mentioned, each of them including a detailed physical and psychological description of the respective person. The database serves two aims. On the one hand, to boost the use of and access to documents generated by the Austrian military and with this to bring the Romanian historical writing on the military border in Transylvania closer to the primary sources. On the other hand, to complement, for the territory of the former military border, the vital registration data provided by parish registers with social history data that can improve life course reconstruction and analysis.
\end{abstract}

Keywords: Historical databases, Austrian Military Border, Transylvania, Habsburg Monarchy, Military history 


\section{Introduction}

Solid historical writings on the topic of the Austrian military border in the area of Transylvania and the Banat are few in numbers and rather outdated in terms of approach (Selectively: Bernath 1960; Göllner 1973; Șotropa 1975; Tutula 2003). Dedicated research tools (bibliographies, glossaries, collections of published sources) are scarce, while electronic databases lack entirely. The interest in the topic dates back to the $19^{\text {th }}$ century, but it materialized mainly in studies or monographs focusing on a single regiment, or ethnically tailored. Hungarian historians have usually written about the Székely regiments, while Romanians undertook research on the Romanian units (short historiographical overviews by: Tutula 2003; Popovici 2018). In the last twenty years, the historical literature on Romanian language, despite a revived interest in the topic, focused mainly on the legacy of the military border (school funds, patrimonial communities, demographics, the border guard mentality, etc.) than on the actual time of its functioning.

This refocusing is the result of many factors, one of them being the ever increasing neglect of the main primary sources: the archives of the border guard regiments. The greater part of the latter has been kept in Vienna, ${ }^{1}$ while those that can be accessed in Romania more likely address aspects of administrative organization (sanitary and health issues, orphans and widows, primary education in the military border $)^{2}$ than military life. On the backdrop of the collaboration of one of the present paper's authors with the researchers at the Institute of National History in Zagreb, between 2015 and 2019 (http: / /croatian-frontier.com /?lang=en) and due in equal measure to a recent doctoral research conducted by another author, ${ }^{3}$ the respective sources were brought back into the focus. Subsequently, surveys in the Viennese War Archives took place between 2018 and 2020 within a project dedicated to the Romanian officers in the Habsburg army, ${ }^{4}$ and a large part of the documents addressed in this paper have been identified. Another set of primary sources, generously provided by colleagues from Croatia, ${ }^{5}$ allowed comparisons between Transylvania and the Banat on the one hand, and the Croatian military border on the

\footnotetext{
${ }^{1}$ Österreichisches Staatsarchiv (AT-OeStA)/ Kriegsarchiv (KA), Personalunterlagen (Pers), Musterlisten und Standestabellen der k. k. Armee I (1740 (ca.)-1820) (MLST I), Grenzinfanterieregimenter (GIR) Nr. 1 - 17, 1742-1848; Idem, Grenzverwaltung der Grenzinfanterieregimenter (VerwGIR) Nr. 1 - Nr. 17, 1803-1823. Detailed online catalogues and archive plan at: https: / /www.archivinformationssystem.at larchivplansuche.aspx.

${ }^{2}$ Romanian National Archives (RNA), Bistrița-Năsăud County Service, Fund: Regimentul II de Infanterie Nr. 17 Năsăud; RNA, Brașov County Service, Fund: Regimentul românesc de graniță nr. 16 infanterie Făgăraș (1768-1856); RNA, Covasna County Service, Fund: Regimentul nr. 2 infanterie secuiască Târgu-Secuiesc (1763-1848); RNA, Harghita County Service, Funds: Regimentul 1 infanterie secuiesc (1770-1858); Regimentul I de Cavalerie Secuiesc de Graniță (1779-1852); RNA, Caraș-Severin County Service, Fund: Regimentul de Graniță Româno-Bănățean nr. 13 Caransebes.

${ }^{3}$ Csaba Horváth, A 11. székely határör-huszárezred tisztikara (1762-1848) [The Officers' Corps of Székely/Szekler Border Guard Hussar Regiment No. 11 (1762-1848)], ongoing doctoral research at Babeș-Bolyai University Cluj-Napoca.

${ }^{4}$ The first one undertaken by Ph.D. student Csaba Horváth in November 2018, the second one undertaken by Dr. Sandra Hirsch in July 2019.

${ }^{5}$ Our gratitude goes to Dr. Alexander Buczynski and Dr. Vedran Klaužer for their constant support and for helping us with the documentation on the Croatian regions of the Austrian Military Border, for comparative purposes.
} 
other hand, in terms of structure and contents of the (apparently) standardized regimental paperwork. As a result, a digital model for structuring and storing the information from the respective documents has been built, which constitutes the object of this paper (https://istoriagranitei.ro/proiect-roha-cs/). Before moving on to describing the electronic tool, we believe that given the specificities of the topic, a short historical introduction regarding the history of the military border would be welcome.

\section{The early history of the Austrian military border (16 ${ }^{\text {th }}$ to $18^{\text {th }}$ century)}

The Austrian military border had sparked the interest of the historians since the time of its functioning, and the first solid monographs have been written in the second half of the $19^{\text {th }}$ century (Vaníček 1875; Schwicker 1883). Other major works have been published between the 1960s and the 1980s (Amstadt 1969; Rothenberg 1960; Rothenberg 1966; Rothenberg 1970), while in the last two decades, the interest has started to slide towards the "new military history", which includes, among others, social history approaches and the contextualization of the military activity and of the servicemen in relation to the civilian world of the time (e.g. Jesner 2013).

The historic origin of the Austrian military border descends in the $16^{\text {th }}$ century, when a series of captainships ('Kapitanate') have been organized in Karlstadt and Warasdin, whose main military objective had been to resist the Ottoman advancement. In time, these military districts have extended geographically and numerically, covering the entire south border of the monarchy and forming a defense cordon that started at the Adriatic and ended in the North East of Transylvania. There was also an idea to organize such militarized areas in Bucovina, but it had not been put into practice (Rothenberg 1966, 8-17; Șotropa 1975, 60-61). It was not only the Habsburg monarchy that had organized such militarized areas at its frontiers, but also the Russian Empire, the institution of the militarized border having its origin in older practices of the medieval times (Rothenberg 1966, 3-7). The Austrian military border did not take the shape of a compact a compact cordon everywhere, rather, as it advanced towards the east, the militarized areas would be entwined with civilian ones. In Transylvania, for example, it was not only that some neighboring villages would end up being militarized and others would not, but even within the same village, some would become border guards (with all the associated rights and duties), while others would not.

During the reign of Maria Theresa, the old captainships had been reorganized and replaced with regiments established on a territorial basis: the generalship of Warasdin had two infantry regiments and one cavalry regiment, while the one in Karlstadt had four infantry regiments and one cavalry regiment. Between 1749 and 1750 , the border area commanded by the ban of Croatia had been reorganized. Here functioned two infantry regiments and one Hussar regiment. Between 1747 and 1753, the Slavonic military border, composed of three infantry regiments and one Hussar regiment went through a similar reorganization process. Overall, the reorganization of the Austrian military border in this time brought a greater standardization and disciplining of units, as well as their passing under the direct command of the Aulic War Council (Hofkriegsrat) (Rothenberg 1966, 18-26). 
In the early 1760 s, the issue of extending the military border towards the east started to be raised, for both military reasons (the need to recruit corroborated with financial problems, the need to secure the South-East border with the Romanian Principalities, by then under Ottoman rule), as well as political reasons (the consolidation of the imperial positions against the provincial estates). In 1763-1764, the military border in Transylvania had been organized, which included two Romanian and two Székely infantry regiments, a regiment of Székely Hussars and one of Romanian Dragoons. The latter was short-lived, being disbanded in 1771 and its recruitment area divided between the Székely Hussars and the two Romanian infantry regiments. Further on, until the disbandment of the border in 1851, four infantry regiments and one cavalry regiment had functioned (Benigni von Mildenberg 1834, X-XI; von Wrede 1903, 334; Göllner 1973, 30-44). In the Banat the organization of the military border started after 1766. Initially there have been organized Hussar squadrons, infantry battalions and two infantry regiments, and through successive reorganizations, until the beginning of the $19^{\text {th }}$ century, it came down to three infantry regiments.

The border guards, which originally activated only against the Turks, started to be used in the wars against European powers in the period of the Seven Years War (1756-1763), when these irregular troops, using unconventional, 'small war', combat tactics, have sometimes placed the Prussian line infantry in difficulty. In 1757 , for example, the Croatian border guards have succeeded in reaching, for a short time, even Berlin (Rothenberg 1966, 41). In the second half of the $18^{\text {th }}$ century and early $19^{\text {th }}$ century, the border guard troops from Transylvania have been used both in the conflicts with the Ottoman Empire, including occupation of the Romanian Principalities, as well as in the wars against France (Göllner 1973, 134-135).

Leaving aside its defensive purpose and soldierly aspects, the military border has signified for the majority of its inhabitants, an important change of social status as well. As the Austrian state had invested in the modernization of these areas in terms of education system, sanitary and epidemic control, population register, regularization of villages, etc. a specific mind set developed in time (Sabău 2015), which differentiated the militarized area from those left under civil administration, where serfdom and the early-modern system of estates still functioned.

\section{The Austrian military border in Transylvania and Banat}

As mentioned above, the first plans to extend the military border towards Transylvania belonged to General Adolf Nikolaus von Bukow, who had drafted projects in this regard as early as 1761 . The initial plan stipulated the creation of five infantry regiments of 3000 soldiers each and two cavalry regiments of 1000 soldiers each. Von Bukow's proposal envisaged that servicemen would be drafted only from among the free people, in order for the liberation of the serfs (and with it the injury to the provincial estates, and internal tensions in a time of war) to be avoided. In the case of Romanians, regiments were to be organized exclusively from Greek-Catholics (Göllner 1973, 29). 
However, the reality in the field has imposed a different approach: only four infantry regiments and two cavalry regiments have been drafted, and in the case of Romanians they have been mostly formed by freed serfs (or at least by persons and communities with uncertain status, in litigation, such as those from the area of Năsăud / Naszód / Nussdorf). Likewise, if for the Romanian regiment in Năsăud (Border Guard Regiment no. 17) the passing to Greek-Catholicism had been mandatory, despite protests, violent movements and several executions, for the one in Southern Transylvania (Border Guard Regiment no. 16), which was spread out over a much wider area, confessional uniformity had been sacrificed in favor of a faster organization. Protest movements also broke out among Székelys, and repression culminated with the massacre of Siculeni / Madéfalva (7 January 1764), in which the Austrian troops have surrounded and bombed an entire locality in order to make an example for those who opposed military conscription (Göllner 1973, 34-35).

The military border in the Banat had been configured after the territorial transformations between the Habsburg monarchy and the Ottoman Empire brought by the Peace Treaty of Belgrade (1739). Thus, the Banat military area included the land border, as well as the course of the Danube, surveilled by the boats of the Tschaikisten (river flotilla troops). In the 1760s and 70s three border areas have gradually been created: the Illyrian regiment, the German Regiment (no. 12) in Pančevo / Panciova / Pancsova / Pantschowa and a Wallachian battalion. Subsequently, the latter and the first had been merged and became the Border Regiment no. 13 of Caransebeș / Karánsebes / Karasebesch, which was again split in 1838. From the time of the 1848 Revolution it bore the name Romanian Border Guard Regiment no. 13 in the Banat and it fought against the Hungarian revolutionary army (Milleker 1925, 36-65, 207).

The process of the militarization of the Transylvanian border had not been, therefore, smooth and without social turmoil. On the contrary, the military border had brought executions and violent repressions, mass emigrations over the Carpathians, towards the Romanian Principalities, including from the Székelyland, as well as internal conflicts. Some broke out among the new border guards and the foreign officer and NCO corps, others emerged between the army, represented by the general provincial command in Sibiu / Nagyszeben / Hermannstadt and the local border guards on the one side, and the Transylvanian Gubernium, the provincial estates and the nonmilitarized inhabitants of the military border, on the other side. Defections were commonplace, and although they were (in theory) punishable by death (Milleker 1925, 113-124), documents seem to indicate that it was fairly usual for a deserter to be readmitted among the troop. Even in the officers' lists of conduct there was a section dedicated to desertion, which implies the fact that it might have been, in some cases, overlooked and followed by military reinstatement.

The military border had also brought population displacements and changes at the local level. The systematization of the villages, although received with reluctance by the locals, have in time led to the modernization of the habitat and have had a positive social impact (Bolovan and Bolovan 2009, 440). The confessional structure of the area had been modified, especially in the case of the Regiment no. 17 (the $2^{\text {nd }}$ Romanian Border Regiment) in Năsăud. Here, an entire region had gravitated from a 
confessional center (Orthodox) to another (Greek-Catholic), entering into a different system of institutions and the population had, generation by generation, followed a different educational and partially professional path.

The border regiments have been used, over time, both as internal law enforcement, patrol and border police, but also in external armed conflicts. They took part in the war for Bavaria's succession (1778), then in the Russo-Austrian-Turkish War of 1787-1792, when they have been stationed and have fought in the Romanian Principalities. The human losses have sometimes been significant. For example, between 1787 and 1792, 1218 soldiers have died only from the Regiment no. 17 in Năsăud. Between 1793 and 1796, the border guards from Transylvania have fought on the Rhine against the French Revolutionary Armies, between 1796 and 1801 in Northern Italy, while in 1805 they have covered the retreat of the Austrian and Russian troops after the defeat at Austerlitz. They have subsequently participated in the Napoleonic Wars until 1815, fighting in Germany, the Duchy of Warsaw, Italy and France (Göllner 1973, 127-143).

In the 1848 Revolution, the border regiments from Transylvania acted in accordance with the spirit of the times: the Székely regiments have joined the Hungarian revolutionary army (excepts two Hussars squadrons formed mainly by Romanians and a number of officers, including some of Hungarian origin) (Süli 2019, $16,20,27,74,134-135)$, while the Romanian ones had remained loyal to the dynasty. The fact that ethnic solidarity had surpassed imperial loyalism had weighted heavily in the decision of disbanding the border regiments from Transylvania a short while after the revolution (Göllner 1973, 147-163, 173-178). The military border in the Banat functioned for another twenty years, until 1872 .

From a social point of view, the military border had had a major impact, both during the militarization period, as well as afterwards. Despite the short-term negative effects, the military border had represented a factor of modernization in social, economic and educational terms. The most promising sons of the border guards could have even attended military academies. There were cases, however, in which some of them were not allowed to pursue a civilian education path, due to their military duties. It was the case of the future honvéd Major Áron Gábor, best known for manufacturing canons for the Hungarian revolutionary army during 1848-1849. As a young pupil at the Franciscan Gymnasium in Șumuleu Ciuc / Csíksomlyó he was drafted at the age of 17 as border guard in the Regiment no. 15 (Imreh 1974, 223-225). The era of the military border had also brought an economic flourishing of the area, on the backdrop of the exemption of the border guards from taxation (they would pay an annual tax of two Gulden per head of household), but also due to the financial influx brought by the officers' and NCO's salaries. The presence of the technical personnel of the army (carpenters, blacksmiths, etc.) and the necessity of forming local specialized personnel had also contributed to changes in the professional structure of the former communities of serfs (Göllner 1973, 97-126; Bolovan and Bolovan 2009, 438-441).

The military border accounts for another specificity, completely overlooked by the historians of Transylvania, which nevertheless permeates from documents: the very large percentage of disabled individuals, as a result of the wounds from the military 
campaigns. George Barițiu, a prominent $19^{\text {th }}$ century Romanian historian, offers, for the Regiment no. 17 only, the figure of over 8500 disabled soldiers during the period of the revolutionary and Napoleonic wars (Göllner 1973, 142). Such a distinct social environment had surely generated specific forms of integration for the people with disabilities, both at the level of the social relations as well as in regard to professional integration, aspects that will hopefully draw the historians' attention in the future.

As we have previously mentioned, the disbandment of the military border did not mean the end of the border guard mentality, on the contrary: the former border guards have organized in the attempt to save as much of their common assets as possible. School funds have been established, through which studious youths have been supported by means of scholarships, educational institutions have been established, the immovable assets (pastures, forests) have been used to support the economic wellbeing of the border guards' communes and to supply the respective funds. The echoes of the military border have reached even the interwar period, when the interest of a whole generation of historians educated from the border guards' funds have brought the first major contributions to its historical research (Bolovan and Bolovan 2009, 441-444).

\section{The historiographical and practical reasons for the construction of a database dedicated to the military border in Transylvania}

Taking into account the previously presented history of the Austrian military border and, in particular, of its areas from Transylvania and the Banat, the question arises: in what ways can a digital instrument be useful in the study of this historical subject and what is the goal of such endeavor?

We must begin by highlight the knowledge gap between the state of the art on the Austrian military border and Romanian research regarding Transylvania and the Banat. The latter evidently lags behind, even compared with the Croatian or Serbian contributions. On this backdrop of diminished domestic research, interest from abroad has remained equally low. The most recent significant work dedicated to the military border from Transylvania and the Banat by a foreign historian is a doctoral thesis that primarily focuses on the issue of sanitary and anti-epidemic organization, not on the military aspects or social realities of the border areas (Jesner 2013). Thus, if current research policies and interests will not change, it is highly probable for the already existing gap to widen in the future. Given this, we deemed it possible for a digital instrument to encourage research by helping Romanian scholars get in touch more easily with the sources from the War Archive in Vienna and perhaps, through its novelty and uniqueness within the former Habsburg lands, even to attract foreign scholars. It should not be overlooked, at this point, the major impact that a database can have over young students and postgraduates, who may feel more tempted to address a topic if there is a digital tool to spark or augment their interest.

Secondly, the historiography of the military border in Transylvania has always been, and still is, dominated by petty localism. Let aside the ethnical division between Hungarian and Romanian regiments, researchers are interested exclusively in the 
history of their 'local' regiment or company, often only in their home village, a fact that burdens the general perspective and the quality of results. Their research took and still takes place separately and highly incongruently, focusing on minor subjects, and the results are being published in journals or volumes that are sometimes hard to reach even in Romania. An instrument that would allow the comparative analysis of the situation in all of the border regiments, even if it is built by joining minor contributions, of local interest, opens the way towards a new written history of the Transylvanian border and, furthermore, to comparisons with other areas of the Habsburg monarchy.

Thirdly, a database dedicated to the military border, given the structure of the documents (as will be detailed below) opens the way towards linked analyses with one of the already existing population databases, namely Historical Population Database of Transylvania - HPDT (http://hpdt.ro:4080/). The possibility of linking data from military sources and parish records had also been highlighted by historians Alexander Buczynski and Vedran Klaužer for the military frontier in Croatia (Buczynski and Klaužer 2015).

The parish registers from Transylvania, on which HPDT is built, contain, for the end of the $18^{\text {th }}$ century and the beginning of the $19^{\text {th }}$ century, little to no information about the profession or the social status of the population from the military border. Often, it is not even specified in these documents if a person was a military or not. In this way, from the parish registers emerges the image of a relatively socially compact world, and based exclusively on this type of sources, the inner-community differences are almost impossible to apprehend. In contrast, the documents issued by the military administration host a wealth of information regarding the inhabitants that feature in the parish registers only by their name: the marital status and sometimes the family composition, the profession, the monthly income, sometimes physical or character descriptions, the different occupations that they have had during the operation of the regiment, diseases, wounds, deficiencies, cause of death, etc. All these allow for the reconstruction of one's life course, of the family structure and of the inner-community social hierarchy, which, corroborated with the demographic data from the HPDT, can lead to a better understanding of the social and demographic realities of the time.

Finally, in the same prospective register, once built this instrument for the digital storage and ordering of the historical information, the transition towards more elaborated tools can be pursued, in particular towards the Handwritten Optical Character Recognition which would greatly help in making the large quantity of military documents available to historians. It also opens the possibility of extending the research from the purely historic register towards that of Digital Humanities, which should add in terms of both advertising the topic and enhanced research results.

In conclusion, a digital model for storing and organizing information regarding the Austrian military border presents at least four major advantages:

- it would help increase the researchers' interest in the topic (including that of potentially interested students and of international scholars);

- it would encourage overcoming mono-ethnic approaches and localism and, through this, would allow for large-scale comparisons and analyses; 
- it could lead to a significant leap forward in the historical knowledge of the topic, in combination with other already-existing instruments (e.g. HPDT);

- it would provide a potential stepping stone for future developments in the use of Digital Humanities for the research of the same topic, with all of the associated benefits.

\section{The typology and content of the sources - the system of record of the Habsburg army in the area of the military border in Transylvania}

The $18^{\text {th }}$ century, as well as the first two decades of the $19^{\text {th }}$ century, have represented for the army of the Habsburg monarchy a period of continuous restructuring and reform. The external armed conflicts, such as the wars against the Ottoman Empire, the War of the Austrian Succession (1740-1748), the Seven Years War (1756-1763), respectively the French Revolutionary and Napoleonic Wars, but also internal turmoil, such as the uprising led by Francisc Rákóczi the Second (17031711), or the peasant revolts (e.g. the uprising from the Hungarian Pusta of 1735 , which has also been joined by Croatian border guards, the Romanian uprising of 1784 in Transylvania) brought up challenges and forced the military leadership of the monarchy, embodied by the Aulic War Council to take appropriate measures.

The establishment of the Military Academy in Wiener Neustadt (1751-1752), the expansion of the military border in Transylvania (1762-1764), the standardization of the military uniforms (1769), respectively the establishment of the regimental schools (1782) can be counted among the modernizing effects of the constant external and internal military pressure. On this backdrop, the records of the military units and personnel have also been standardized, extended in terms of contents and some of them newly introduced starting with the $18^{\text {th }}$ century.

Further on, we provide a short overview of those types of records of the Habsburg army which have been used in designing the database dedicated to the border regiments in Transylvania and the Banat. It should be noted, though, that our selection does not cover the full typology of such records even for the aforementioned provinces, that full standardization was still far from being achieved, thus differences can occur even between regiments, and that documents bearing the same name might have a different structure and host uneven (richer or meager) information in other regions of the military border.

\section{a. Military monthly tables / Monatstabellen Militär}

Staffing tables (under the general denomination of Standestabellen, Figure 1) were drafted monthly (Monat Tabella), contained nominal information regarding the officer corps and documented any change in numbers that took place in the respective regiment during the respective month.

Thus, they included two types of data: nominal and statistical. Firstly, the document enumerates, at the top (Figure 1, area 1a), the members of the Regimental Staff): the colonel (who was also the commander of the regiment), the lieutenantcolonel, the majors, the chaplain, the accountant, the military bailiff, the adjutant, the 
regiment's physician alongside the battalion's physicians and the assistant surgeons, the foragers, the drummer and the provost of the regiment. The names of all of them are mentioned, as well as their physical presence / absence during the respective month in the regiment, or if they have been detached somewhere else. Likewise, the source also mentions the names of the companies of the respective regiment (identified most frequently by the name of their captains) and the locality in which the company command resides (Figure 1, area 1b). For each company the names of the officers are also mentioned: lieutenant captain, ${ }^{6}$ first lieutenant, second lieutenant and ensign (Figure 1, area 1c). The name (and the rank) of those registered as supernumeraries are also being recorded.

Figure 1. Monthly table (military personnel overview) of the Border Guard Regiment no. 17 from Năsăud (Romanian no. 2), January $1802^{7}$

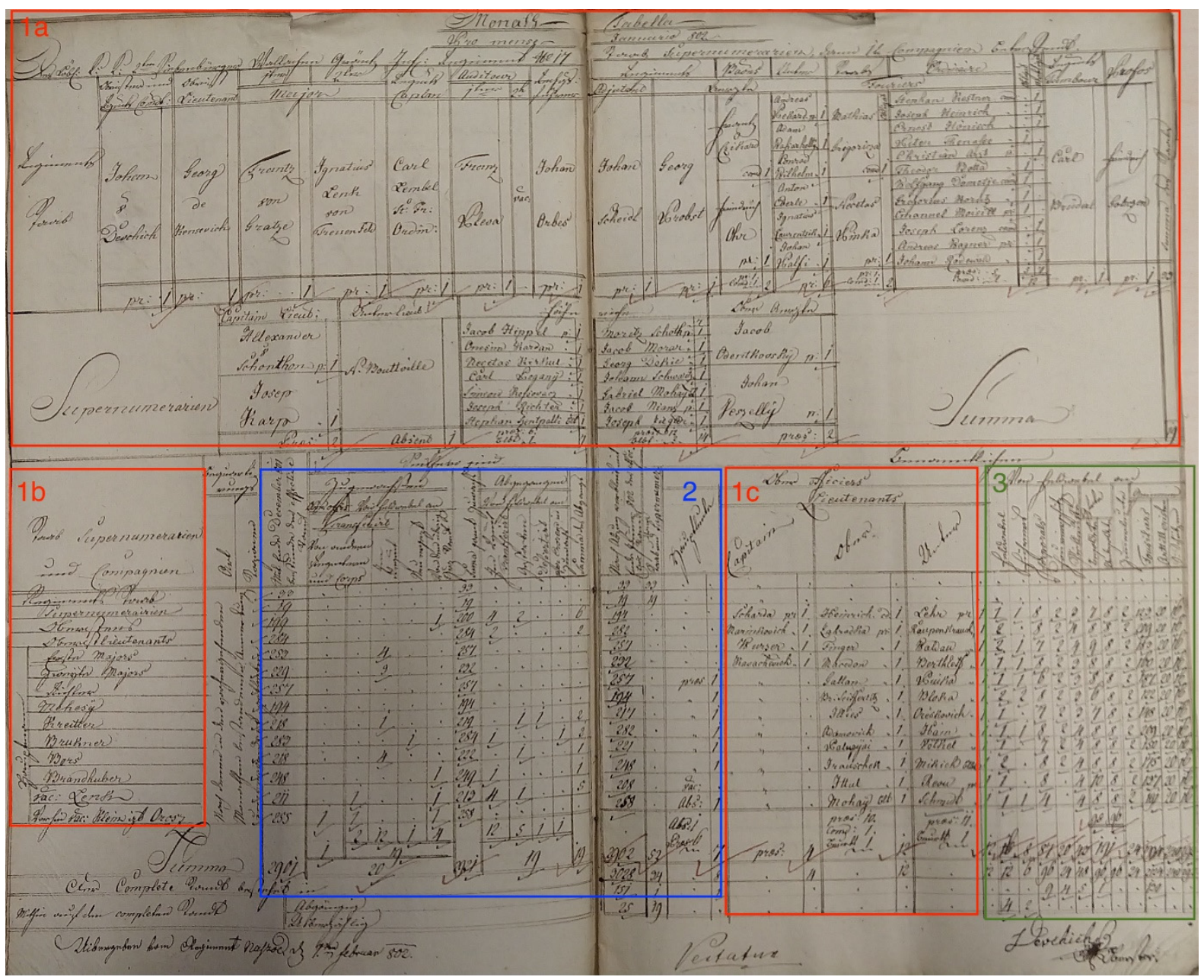

Turning to the statistical part, the table reflects in short the sum of the staff and the movements that took place within the military personnel, each month. For each company is noted the total number of soldiers for the previous month, the number of

\footnotetext{
${ }^{6}$ Rank that existed only within the infantry regiments.

${ }^{7}$ AT-OeStA/ KA Pers MLST I GIR 17 6189, Standestabellen (1802-1804).
} 
those that have left the company (deaths, defections, transfers to other companies / regiments, transfers to the army reserve, retirements, etc.) and the number of those that have joined in (new enrolments, returned deserters, transfers in / from the regiment, etc.) (Figure 1, area 2). Starting with the rank of sergeant downwards, all of the servicemen appear solely as numbers (Figure 1, area 3). Each monthly table has at the end, at the bottom of the page, a date and a place mentioning where the document had been drafted and, if required, other observations.

The description up to this point covered only the first page of this type of document. Further on, its contents detail by name and relevant comments the information recorded in the above described table only through numbers (i.e. the names of those that are detached, the place and motive, the names of those that have joined / deserted / died, advancements / demotions in rank, the relocation of sub-units, etc.). To these tables are added, generally, the lists of recruitments ("assent", Assentlista) and those of transfers (Transferierungslista), which can be particular or collective such as the so-called 'unfit for service lists' (Superarbitrierungslista), which register the complete or partial disability of a serviceman.

\section{b. Monthly tables - Administrative Service I Monatstabellen Verwaltung}

Same as for the military personnel, monthly tables have also been drafted for the auxiliary and administrative personnel of each unit (Figure 2). The latter was divided into several departments as follows: the special personnel included the midwives, the chimneysweeps and the trainees, the spiritual department included the priests, the chaplains and the catechists, the school department included the principal, the training school teacher, the elementary school teachers and trainees (sometimes even priests), the forestry department was composed of forest rangers, the commercial streets' department - the street wardens and street attendants, and the department of paper mills was composed of foremen, journeymen, manservants and apprentices. Depending on the year, the allocation of positions into departments could be slightly different to the presented model (for instance, the forest ranger could appear as 'special personnel'). For each category is mentioned the number registered in the previous month, the number in the current month (by category and in total), as well as if there were new hires or departures in / from these departments. There are monthly tables in which the name of the people is also mentioned, but this does not come as a rule. This first page is followed by others, that add details about the personnel, the physical presence or absence of the employees on the regiment's territory, departures or new hires, observations, etc., similar to the military monthly tables. 
Figure 2. Monthly table (administrative personnel overview) of the Border Guard Regiment no. 17 from Năsăud (Romanian no. 2), May $1805^{8}$

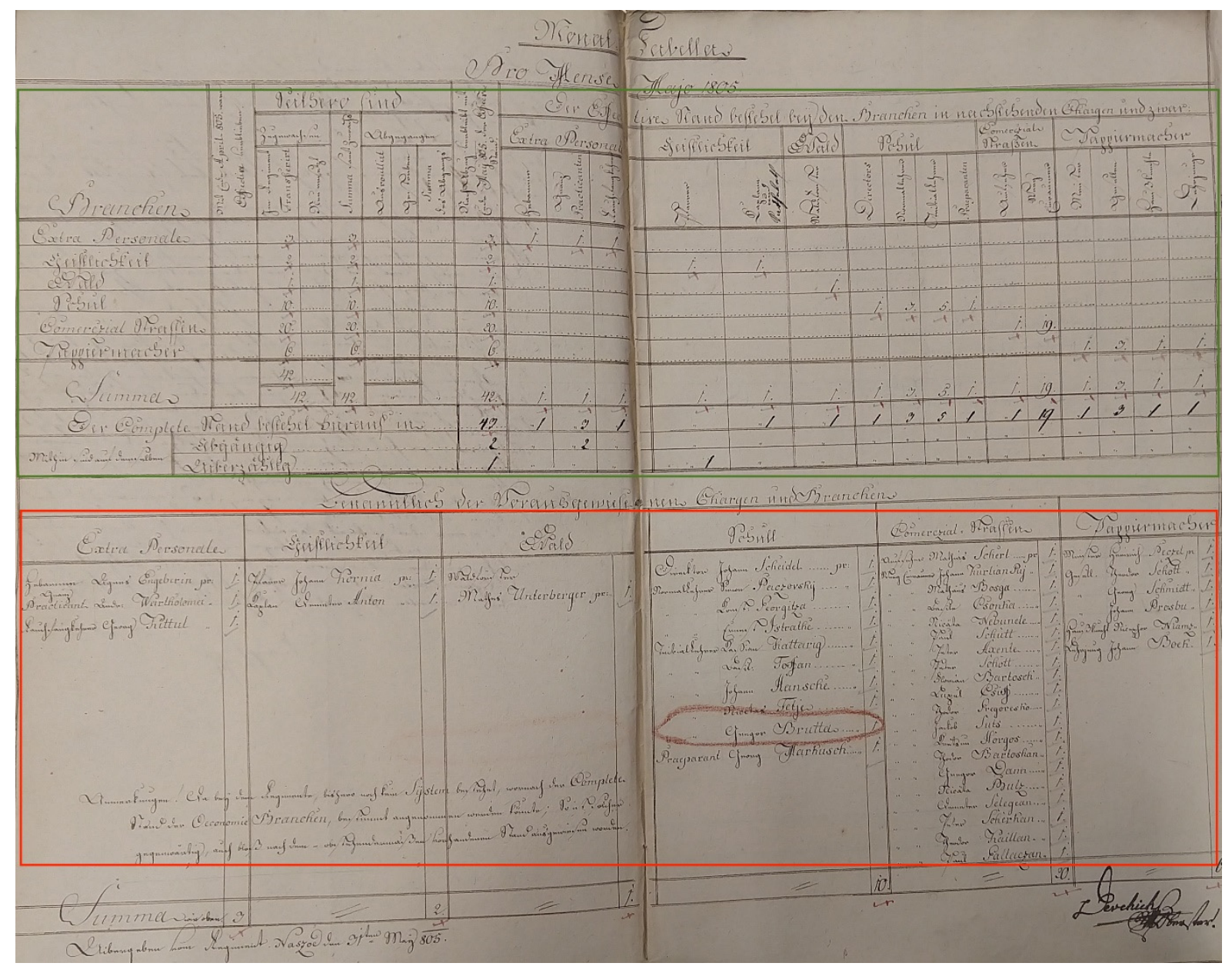

\section{c. Drafts of the salaries of the administrative personnel / Verwaltungs- Besoldungs- Entwürfe}

The payrolls for the employees in the above mentioned administrative branches are grouped according to the respective departments: special personnel, the spiritual department, the school department, the forestry department, the commercial streets' department and the department of the paper mills. They were drawn monthly and included the name of each employee. Besides one's name and the administrative branch in which she / he was included (along with the regiment to which it belonged), such documents also mentioned one's position and the place where one carried her / his activity (it could be a locality from the military border, but also a zone between localities). The 'observations' section mentions the period for which the salary statement is registered, in case it doesn't correspond exactly to the calendar month. The following columns of the table are dedicated to the salary, broken down into: the gross monthly salary, the income tax, the net salary and the way in which it was paid (coins, banknotes, etc.).

${ }^{8}$ AT-OeStA/ KA Pers MLST I VerwGIR 17 6320, Standestabellen (1805-1808). 


\section{d. Muster rolls / Musterlisten}

Among the most enduring types of documents used in the Habsburg Imperial and Royal Army one finds the muster roll (Musterlista) (Figure 3). The muster is the denomination for the military inspection initially undertaken twice, subsequently only once a year (during the autumn), for each regiment. There were also cases in which the inspection had not been held due to certain reasons (e.g. the relocation of the unit in a new garrison). The first muster rolls date back to the early-modern period, but they have been only sporadically preserved before Maria Theresa's reign. They document the unit's servicemen and personnel, from the regiment owner - the colonel, down to the ordinary soldiers. They also include the so-called revision lists (Réfi 2012, 86-87). The system of muster rolls functioned until 1820, when it was replaced by the more modern one of military registers (Grundbuch). However, the latter had not been unitarily introduced, and the border guard infantry units went on using the muster rolls for another two decades (Réfi 2012, 88).

By form and content, muster rolls are relatively similar to the lists of conduct (detailed below). The sequence of names and observations regarding each officer was made in the descending order of ranks, starting therefore with the members of the Regimental Staff. Besides the names, the place of birth and age, the document also registers the religion, marital status and profession of the respective serviceman. If the officer had received any distinction, it was also mentioned. Compared to other sources, these lists offer additional important details, such as the names of children and the measurements of the soldier. The last part of each entry in the table is reserved for observations, which, in this case, actually refer to the evolution of the military career, in chronological order (when the individual enrolled, in what army corps / institution, from what rank did he start and when was he promoted), but also the wedding day, if case be. At the end, another summary table resumes the total number of those registered in these lists, for each rank / office in part, also noting the number of increases and decreases for the covered period of time. 
Figure 3. Muster roll of the Border Guard Regiment no. 17 from Năsăud (Romanian no. 2), $1^{\text {st }}$ Company, $1819^{9}$

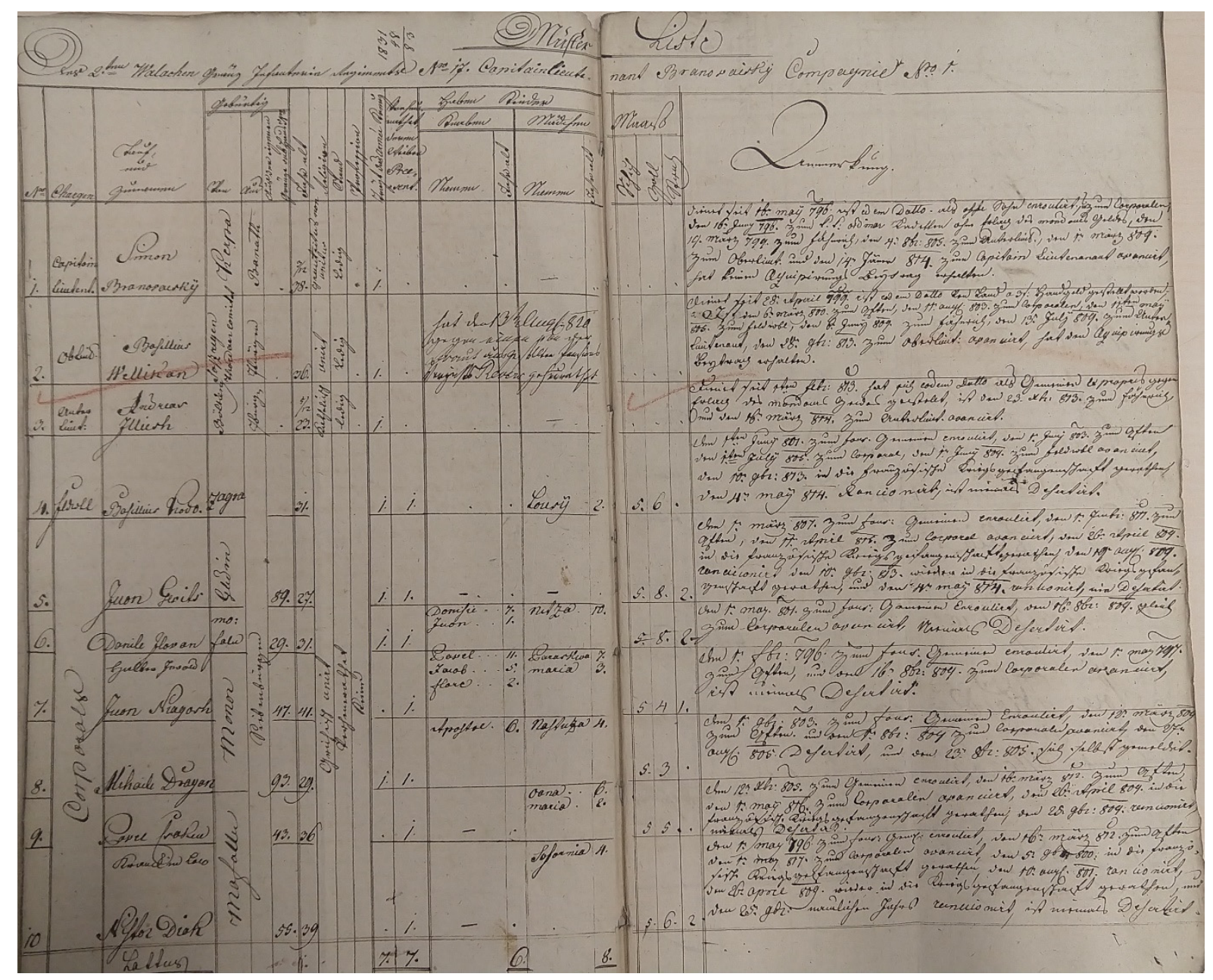

\section{e. Revision lists / Revisionslisten}

Revision lists (a complementary document to the muster rolls) were drawn up at regular intervals, for each sub-division of a regiment, so that we can find separate lists for the Regimental Staff, for the supernumeraries and for each company. The information corresponding to each person is firstly of a personal nature: name, address (the house number), marital status and the number of children. The remarks related to the place where the person was found at the time (in the regiment or detached) and the distinctions received were either merged in a single section (Anmerkungen / 'observations'), or divided into dedicated columns. At the end of the list, a table was drafted, summing up the total current armed personnel of each sub-division of the regiment in comparison to the full staff. We also mention here a document titled Revisions-Tabella or revision table, with an appearance that reminds of the monthly tables (Monatstabellen), including by and large the same information as the lists.

${ }_{9}^{9}$ AT-OeStA/ KA Pers MLST I GIR 17 6174, Musterlisten, Revisionslisten (1819-1829). 


\section{f. Nominal rolls / Nominallisten}

The nominal rolls present a similar structure to the less complex version of the revision lists. Thus, for each soldier from a sub-division of a regiment are mentioned the name, rank and the place where he was found at the respective moment (present in his unit, detached in another station, guarding of the supply store, detached to the sanitary cordon, at the regiment's garrison, at the military cash register, guarding some transfers, sent with postal ordinances, hospitalized or on leave, etc.). At the end there was a brief calculation of the total number of enrollees corresponding to each subdivision of the regiment.

\section{g. Recruitment lists / Assentlisten}

This type of document, drafted in a narrative format, marks the fact that a soldier had been considered for a certain position within a particular unit and evaluated from a medical standpoint. It can be individual (contains the data of just one person) or collective (documents the data of multiple recruits). Here, the regiment and the company to which the person in question belonged, were firstly mentioned. Then, in a few lines, the individual was described: the place of birth, age, religion, marital status, profession, rank and military career up to the moment of enrollment (if there was a previous career). The document is dated (the date of the evaluation as well as the date when the individual entered the unit's personnel). At the end, the laconic and oftentimes cliché observations of the regimental doctor or of his replacement are recorded (i.e. if the person was considered able for the envisioned position) together with the signature of the superior from the General Command of the province, acknowledging the recruitment.

\section{h. Enrollment lists / Enrolierungslisten}

The lists with the recently enrolled soldiers within a certain company of the regiment are documents drafted on a monthly basis, and their length depends, naturally, on the monthly number of new recruits. These nominal tables contain the exact date of enrollment, rank, name, place of birth (city, country / province), age, religion, marital status and the civilian profession of each recruit. The table is dated and signed by the colonel of the regiment or by his replacement and by the commanding-general of the province.

\section{i. Transfer lists / Transfererierungslisten}

This type of document was written in two different forms (narrative and tabular), comprising however the same information. The transfer of a person from a regiment to another, or from a sub-unit of the regiment to another, was documented through noting firstly the name of the unit /company of origin and of the unit / company where the said transferred would go. For accuracy, regardless of being of a tabular form or not, the file with the transfer always had in the upper-left side the name of the regiment from which the departure took place, while in the upper-right side the name of the regiment of arrival. 
In addition, the date of transfer is attested, as well as other details relative to the soldier's origin, his rank, age, religion and marital status. Other particularities covered in this document refer to his career up to that point, to his conduct, performance in battle or physical measurements. The tabular form nearly always included the equipment which the transferred owned (the name, sometimes also the color or material and the number of units of each piece of the uniform). Sometimes, the number and date of the ordinance which established the transfer in cause was registered.

\section{j. Lists of returned deserters / Präsentirungslisten}

The lists with the names of deserters represent, in fact, the registration of one deserter returning to the regiment of origin. These are, generally, individual tables (with a single name) and contain information relative to the regiment and company from where the said person had left, the date when he had deserted and the date when he returned, the rank / occupation, the date of birth and age (sometimes the religion, marital status and profession were also added), and whether he served in other military corps. Additionally, the most interesting remarks for the historical and sociological research are noted in the columns which question the reason for desertion, the wrongful taking of the equipment when deserting (and if the taken objects have been returned), the places where he had stopped in the meanwhile, and the place where he was found or from where he returned. The soldier in question confirms the statements regarding his person. The doctor of the regiment declares whether the returned deserter had been examined and whether he had been found fit for service. The document is signed by a clerk of the War Commissariat and by the regiment's physician, or by his replacement.

\section{k. Medical certificate / Ärztliches Zeugnis}

The medical certificate is a particular document, issued when necessary, having the form of a clean bill of health. Thus, a certificate could contain the name and rank of one or more soldiers, the reason why they are not prepared or fit for a certain activity, namely the disease or condition they suffer from, if they were injured, etc. The document also includes the date of elaboration and the signature of the military doctor and of the captain of the company. The medical certificate is often mentioned in the observation section of the nominal lists (when a soldier is not present, as part of the motivation of absence).

\section{Lists of conduct / Konduitenlisten}

This type of document had been introduced following the Prussian model, during the Seven Years War, but unfortunately those elaborated before 1823 have not been kept. One of the most complex sources for the personnel of the Habsburg army presents itself in the form of a register (Figure 4) which contained the individuals from a regiment, for a certain period of time. Their registration could take place annually, but also biennial. 
Figure 4. List of conduct of the Border Guard Regiment no. 17 from Năsăud (Romanian no. 2), $1824^{10}$

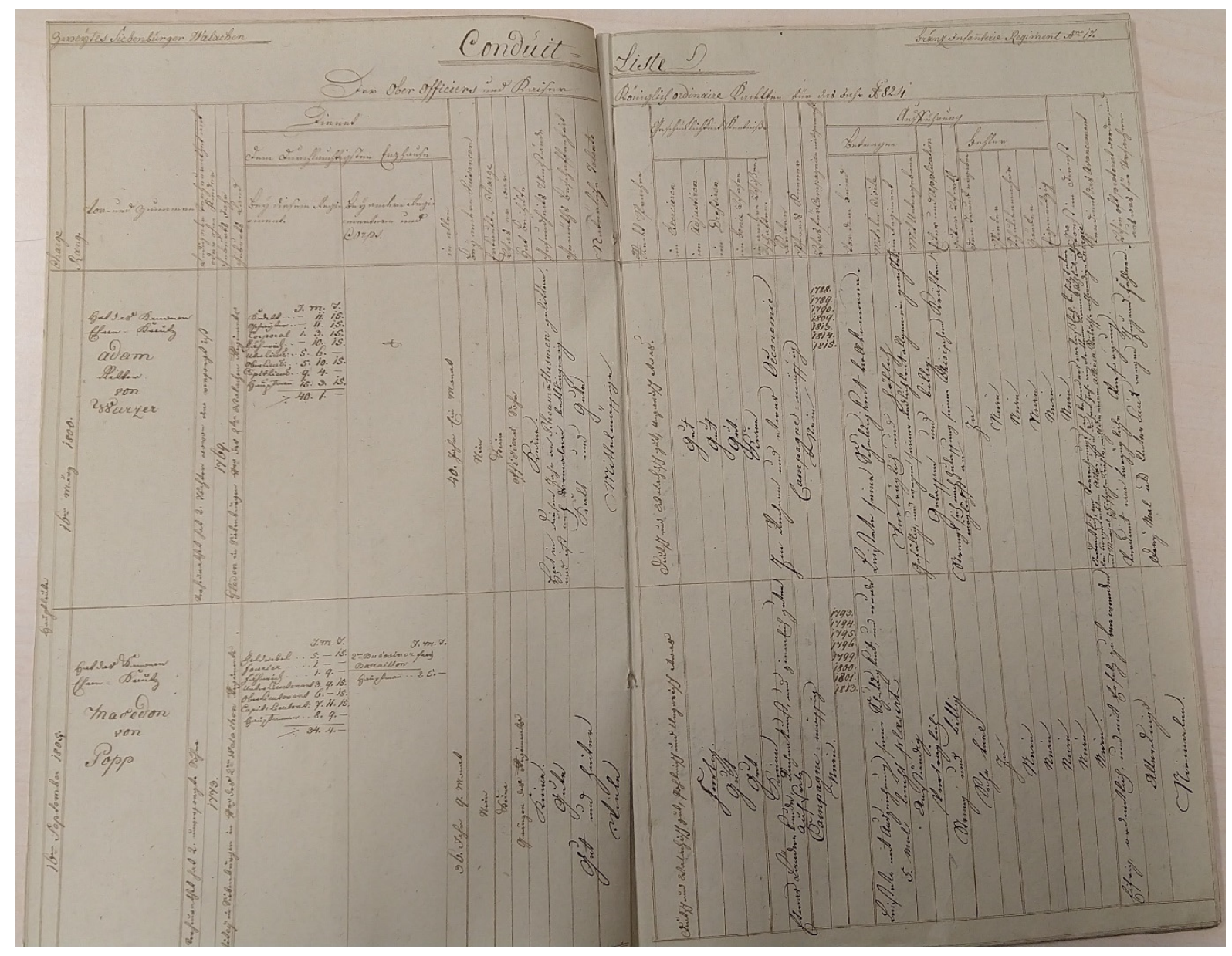

The conduct lists register the aptitudes of the main officers (captains, lieutenant-captains, first lieutenants, second lieutenants, ensigns), of the cadets and of the non-commissioned officers (sergeants, corporals), in the descending order of ranks. The complexity of the document is given by the detailed information regarding each person. Usually, two pages are allotted to each officer. At the beginning of the first page, the current rank and the date when it had been obtained are noted. The first part of the table contains personal information (name, origin, marital status, number of children). Three sections follow, recording the military units in which the respective person has served (and the duration), namely: within the current regiment, in other army corps of the House of Austria, or if he had served in foreign armies. These sections also register the ranks one held in each unit, thereby conveying the entire military career of a serviceman. It is also the first half of the table that generally contains, if applicable, the social status of the enrollee, namely if he was a noble, if he was a noble's son or the son of an officer, or if he received an allowance. There is a dedicated section for desertions, if applicable. The table was completed with data

10 AT-OeStA/ KA Pers CL Grenze 498, Grenzinfanterieregiment Nr. 16 (1824-1849), Grenzinfanterieregiment Nr. 17 (1824-1840). 
regarding the physical and mental health, the physical, military and intellectual capacities and attributes of the individual (what languages he spoke, if he was a good horseman, if he had knowledge in engineering or other domains, what was his behavior in relation to subordinates, to civilians or in front of the enemy, etc.). The campaigns in which one took part are also mentioned. At the end, one's defects or vices are mentioned (consumer of alcoholic beverages, gambler or card player, indebted, insolent, selfish, etc.). One of the final observations made reference to the respective serviceman deserving or not the promotion in rank - sometimes with specific regard to being promoted before a comrade of the same rank. The register of the lists of conduct also includes short tables with the name and rank of those accepted in or departed from the respective army corps, during that year(s).

This type of source opens, thus, research possibilities in various fields of historical research and they are, probably, the most important type of individual military documents included in our database. Conduct lists can open, through the richness and diversity of the stored information, the path towards a much more insightful knowledge of the officer corps of the Habsburg army originating from or stationed in Transylvania, complementing the existing steps already taken in this direction (Maior 2004).

\section{General principles of constructing the database}

The database is constructed in MySQL and is hosted, momentarily, on a server of the Babeș-Bolyai University of Cluj-Napoca, with access through redirection from the website of the project (http://istoriagranitei.ro/wp/proiecte/rohacs/rohacs-database 1). It includes, in this version, a number of 36 tables and 444 columns. Access is provided through a bilingual interface (English-German), built in Ruby on Rails, with different facilities for public users (see below section 7.c. Public Access) and for registered users (only the latter can fill in data). The structure of the database includes three types of tables / forms for data introduction (from the point of view of their relation to the primary source and to the other components of the digital instrument): a main normalization table, source-oriented tables and secondary normalization tables.

The main normalization table ('Individuals/ Personen') accommodates basic biographical information regarding the persons mentioned in the documents (soldiers and civilians), in different moments of their lives and careers. The information from it is retrieved in the majority of source-oriented tables, in this way avoiding the repetition of the same data an indefinite number of times. For example, if a military serves in the same unit for three years, with the same rank, and subsequently for three other years in another unit, or in the same unit but with a different rank, each of these situations will be separately registered in the normalization table and retrieved in the sourceoriented tables by case - i.e., instead of $72\left(3^{*} 12\right.$ months $\left.{ }^{*}\right)$ recurring mentions of the same person in a single type of document, let aside other mentions in other documents, the database only registers the two different instances, reused in all the other tables according to the requirements.

The source-oriented tables reproduce as accurately as possible the structure of the archival documents. The information about persons that already exist in the 
principal normalization table are retrieved from there, while for other information different types of registration fields are used, according to the specifics of the source. Some source-oriented tables are of a statistical nature, as the object of their information is constituted by the unit (the regiment) or the subunit (the company), and not by the person.

Both the main normalization table, as well as the source-oriented ones use, in their turn, information from the secondary normalization tables, of which the 'Sources / Quellen' table ensures the referencing of the information in the archival system, thus allowing its use for scientific purposes.

The principles from which we have started in the construction of this digital instrument are rooted in the best practices proposed by the state of the art (Mandemakers and Dillon 2004), but equally take into account the specifics of the sources, the historiographical situation and the local realities, as well as the mediumand long-term objectives of our initiative. Being a historical database, which is built starting from documents with structured or partially structured information (although narratives are not missing either), we tried to maintain, as much as possible, the relation between the data-entry forms and the original source, however we have opted for a certain level of normalization of the information starting from the moment of source transcription and data input.

There were two main reasons that have prompted us to do so. On the first hand, the quantity and diversity of the existing documents forced us to sample the sources and we have lacked from the beginning an exhaustive overview on their typology and content (such a process of comprehensive primary documentation would be extremely costly and time consuming in the absence of a dedicated stand-alone project). Hence, we have used the sample documents for constructing the current version, taking however into consideration the realistic possibility that new documents, with a different structure and nature of information, would have to be accommodated in the future.

Secondly, the typology of sources and the complexity of their structure have imposed, in many cases, the creation of more forms dedicated to the same type of source, each of them covering different sections of it. The monthly personnel tables, for example, contain two completely different types of information: nominal data down to the level of the junior officers, and statistical data for the troop, non-commissioned officers and auxiliary personnel, which has imposed that each of them be distributed in a different form, out of technical, transcription-related, data-input and data-output reasons. Statistical information can be much more easily and quickly transcribed in spreadsheets (even turning to crowdsourcing, as it does only require minimalistic paleographical knowledge) from where it can be subsequently imported into the database. The nominal information (a large part of it person names and place names), which requires more advanced paleographical knowledge, can be more easily filled-in directly in the database forms, by turning to the normalization tables that register the persons or the localities.

An additional reason for which we have turned to the normalization tables has to do with diminishing redundant information in the database. Provided that a very extensive set of documents with a monthly recurrence refer to a relatively constant 
number of persons from the same geographic area, the name of the same individuals and the local toponyms have an especially high frequency of occurrence. Thus, persons have been concentrated into a single table ('Individuals / Personen'), while administrative units in three hierarchically structured tables ('Counties / Komitate', 'Districts / Bezirke', 'Localities / Orte').

In our decision, we have also taken into account the fact that one of the main objectives of this digital instrument is to promote the research of the history of the military border among students and local historians, to stimulate the interest towards a research subject that slides towards localism precisely because it has lost, to a great extent, contact with the primary sources - both due to the physical distance, and even more so due to the paleographical barrier. Whereas, for the achievement of this goal, it must be user friendly, both as an interface, as well as in the logic of use and difficulty in relation to the level of training of the latter, and the onomastic and toponymical normalization tables help a great deal in this regard.

Furthermore, the database, in its current form, is only the by-result of a shortterm research project. Its future evolution - mainly populating it with information, but also expanding its architecture - depends, to a great extent, on support attracted from the main research-funding agencies, as well as from local stakeholders in the area of the former border guard regiments, interested in supporting professional research for local history purposes. By normalizing a part of the information even from the extraction stage, the construction and the data-entry process were quickened and we have been able to provide an instrument feasible enough to act as argument for its future development.

Not lastly, if required, in the current form, the normalization tables can be easily adapted to a literal transcription of the information from the sources, either more simply, through adding various onomastic and toponymical variations in dedicated fields, or in a more complex way, by including them as separate entries. This last solution, though it would considerably increase the accuracy of the registered information from a linguistic standpoint (mainly person names and place names), would also mean bearing a much slower rhythm of data input.

In what follows we provide a thorough description of the database tables and their columns in the form of a database manual, detailing, where necessary, the rationing behind our options. 


\section{The structure of the tables and the data entry manual}

\section{a. General principles}

As a rule of thumb, the general principles for data-entry in use with the Historical Population Database of Transylvania also apply to DFMBT, as following (Bolovan et alii 2019, 12-18):

- unreadable information within the source, either letters, the whole word or multiple words, will be marked by means of a double question mark: '??' (e.g. 'Nia??', 'Nia??z', '??z'). The same symbol should be placed at the end of a word if the dataentry operator is unsure about her/his reading;

- in case of two possible lectures of the same name, both interpretations will be provided, with the sign '@' between them (e.g. 'Niamz@Nianz');

- logically incompatible or conflicting pieces of information provided by a primary source will be marked by means of a double exclamation mark: '!!'. Additional details will be provided in the field REMARKS;

- markings meant to signal repetition of previous explicit information in the original source (e.g. '", '-"-', 'ditto') will not be inputted in the database. Instead, the explicit information they were meant to replace will be filled in;

- various types of brackets in the original document (e.g. '()', ' $/ l$ ', '[]', ' \{\} ') will be copied into the database as round brackets '()', regardless their original form;

- later corrections or interventions in the original text will be signaled by the symbol double percentage ' $\% \%$ ', placed at beginning and at the end of the respective correction / intervention;

- words or sentences barred in the original source will be signaled by means of a single percentage '\%' at beginning and at the end. If the source features both the barred and the correct information, the latter will be inputted into the respective fields of the database, while the former will be registered in the field REMARKS;

- marking out of words or phrases in the original source (usually by means of underlining) will be mentioned in the field REMARKS;

- dots, question marks or any other markings used within the source which have not been mentioned above will be transcribed only if they bear significance.

\section{b. Instructions specific to forms}

\section{Table 'INDIVIDUALS / PERSONEN'}

This is the main normalization table of the database and it is indispensable for the proper functioning of all other tables that include nominative information (i.e. most of the source-oriented tables). It is worth noting that this table not only captures unalterable information about people (date and place of birth, physical characteristics, etc.), but also the professional situations in which they found themselves at a given moment in time. Therefore, the same person can feature in this table multiple times, depending on the career moment which is mentioned by the sources. To facilitate the entity resolution process, the different mentions of the same person can be linked manually. 
Figure 5. Data-entry form for Table 'Individuals / Personen'11

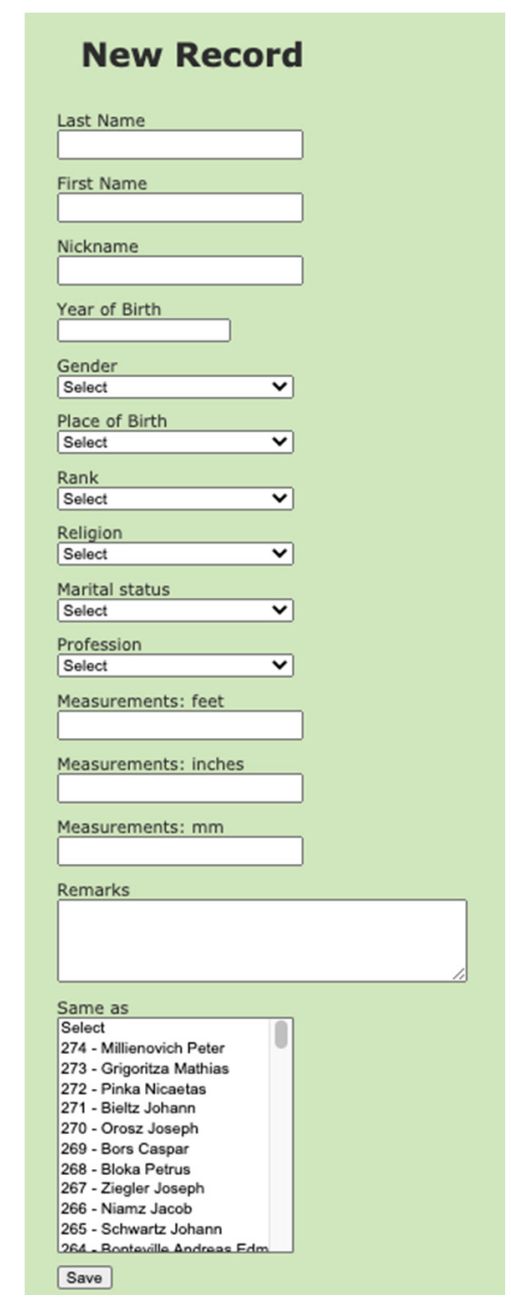

LAST NAME I ZUNAME. The person's last name will be filled in this field, following the exact onomastic form from the archival source.

FIRST NAME / VORNAME. The person's first name will be filled in this field, following the same rule as for the last name.

NICKNAME I NICKNAME. Other onomastic information (e.g. nickname, middle name, paternal filiation) will be filled in this field, following the rule above.

YEAR OF BIRTH / GEBURTSJAHR. The person's birth year will be filled in.

GENDER / GENDER. The person's gender will be selected from a value list with two options: Male and Female. Given the particularities of the sources, the gender will be inferred either by means of explicitly recorded relationships (e.g. wife, daughter,

\footnotetext{
${ }^{11}$ http://82.208.133.141:3020/mbindividuals/new.
} 
mother), or by means of onomastics. However, in case of gender-neutral first names, and lacking any other clarifications in the source, the field will be left blank.

PLACE OF BIRTH / GEBURTSORT. The place of birth will be selected from a dropdown menu (Table 'Localities / Orte'). If it does not feature in the respective table, it should be first added there manually.

RANK / RANG (CHARGE). The person's rank will be selected from a drop-down menu (Table 'Ranks \& Roles'). If it does not feature in the respective table, it should be first added there manually

RELIGION / RELIGION. The person's religion will be selected from a value list. If it does not feature in the respective list it can be added by the database administrator. If the religion is unclear, the field should be left blank and the situation described in the field REMARKS

MARITAL STATUS / EHESTAND. The person's marital status can be chosen from a value list with three options: 'Married / verheiratet', 'Widower / witwer', and 'Single / ledig'. Further options can be added by the database administrator, upon request. If the marital status is unclear, the field should be left blank and the situation described in the field REMARKS.

PROFESSION / ZIVILBERUF. The person's profession will be selected from a dropdown menu (Table 'Positions / Stelle'). If it does not feature in the respective table, it should be first added there manually.

MEASUREMENTS: FEET / MAßE: SCHUH. The information will be filled in as / if provided by the source.

MEASUREMENTS: INCHES / MAßE: ZOLL. Same as the previous field.

MEASUREMENTS: MM / MAßE: STRICH. Same as the previous field.

REMARKS I ANMERKUNGEN. The utility and usage of this field are self-implicit and already highlighted above. The data-entry operator can use it to transmit towards the end-user any information believed to be relevant.

SAME AS / GLEICH WIE. This field allows manual linkage between various instances of the same person within the table (multiple selection is allowed) and with it, opens the way towards reconstructing career paths in a semi-automated manner.

\section{Table 'RELATIONSHIPS / BEZIEHUNGEN'}

INDIVIDUAL 1 / PERSON 1. The first person will be selected from the drop down list. 
RELATIONSHIP / BEZIEHUNG. The relation between the two persons will be selected from the value list. The selected value will always describe the position of the first person (e.g. if the first person is the father and the second person is the son, the selected relationship will be 'Father / Vater'.

INDIVIDUAL 2 / PERSON 2. The second person will be selected from the drop down list.

SOURCE / QUELLE. The source mentioning the relation will be selected from the drop down list (Table 'Sources / Quellen').

SOURCE REMARKS / ANMERKUNGEN. Any other information in the original source regarding the respective relationship will be filled in here.

\section{Table 'LIST OF CONDUCT / KONDUITENLISTE’}

This is one of the most important tables of the database in terms of richness, diversity and usefulness of historical data. However, despite de structured form of the original source, which presents itself as a large table, the variety of information encompassed by the officers' characterizations and the fact that each of their features is narrated, with differences from case to case, made it difficult to generate standard sets of values for each particular aspect. For this reason, we have chosen to keep the original tabular structure and transcribe the narrative content, which implies that future normalization procedures will be required in order for the information to undergo serial analyses.

OFFICER / OFFIZIER. To be selected from the drop down list (table 'Individuals / Personen'). It should be carefully checked that not only the onomastical data, but also the biographical (year and place of birth) and career (rank) data match the information from the source. If there are differences in the biographical information, a closer examination of the officer is required. If the already recorded biographical information matches the source, but the career information differs, a separate entry should first be made in table 'Individuals / Personen' with the respective rank, which will be then used for the current entry in table 'List of conduct / Konduitenliste'.

TIMESTAMP / ZEITMARKE. The date at which the original document was drafted will be filled in. If parts of the date are missing in the original document, only the existing information will be recorded.

SINCE WHEN / SEIT WANN. The date of advancement in the current rank will be filled in, according to the document.

MARRIED / VERHEIRATET. Checkbox should be ticked if applicable. 
NO. OF CHILDREN / ANZAHL DER KINDER. The number of children will be filled in, as recorded in the source.

NOBLEMAN / EDELMANN. The nobility status will be selected from a dropdown menu (Table 'Nobility / Adelsstand'). If it does not feature in the respective table, it can be added manually.

SON OF OFFICER / OFFIZIERSKIND. Checkbox should be ticked if applicable.

WHAT HE WAS I WAS ER WAR. Previous profession or social status will be filled in, as registered by the source.

HAS ALLOWANCE / HAT BEIHILFE. Checkbox should be ticked if applicable.

IF HE EVER DESERTED / OB JEMALS DESERTIERTE. Checkbox should be ticked if applicable.

STATE OF HEALTH / GESUNDHEITSUMSTÄNDE. The information under the respective column header will be transcribed exactly as recorded in the source. See also above: 6.a. General principles.

The same rule applies to the following fields:

STATE OF MIND / GEMÜTSBESCHAFFENHEIT.

NATURAL TALENTS / NATÜRLICHE TALENTE.

SPOKEN LANGUAGES / REDET SPRACHEN.

CAN READ/WRITE LANGUAGES / KANN LESEN UND SCHREIBEN (SPRACHEN) ABILITY/DEXTERITY TO EXERCISE / GESCHICKLICHKEIT - IM EXERZIEREN ABILITY/DEXTERITY TO ADJUST / GESCHICKLICHKEIT -IM ADJUSTIEREN ABILITY/DEXTERITY TO TAME / GESCHICKLICHKEIT - IM DRESSIEREN ENGINEERING KNOWLEDGE / KENNTNIßE - IM GENIEWESEN KNOWLEDGE OF OTHER SCIENCES, ARTS AND TRADES / KENNTNIßE - IN ANDEREN WISSENSCHAFTEN, KÜNSTEN UND PROFESSIONEN

CAMPAIGNS (PARTICIPANT) / WAS FÜR KAMPAGNEN MITGEMACHT HAT CONDUCT/BEHAVIOUR REGARDING THE ENEMY / AUFFÜHRUNG/ BETRAGEN - VOR DEM FEIND CONDUCT/BEHAVIOUR REGARDING CIVILIANS / AUFFÜHRUNG/ BETRAGEN MIT DEN ZIVILEN

CONDUCT/BEHAVIOUR INSIDE THE REGIMENT / AUFFÜHRUNG/ BETRAGEN IM REGIMENT

CONDUCT/BEHAVIOUR WITH SUBORDINATES / AUFFÜHRUNG/ BETRAGEN MIT UNTERGEBENEN

CONDUCT/BEHAVIOUR FERVOUR/PURPOSE / AUFFÜHRUNG/ BETRAGEN EIFER UND APPLICATION 
CONDUCT/BEHAVIOUR GOOD HOST I AUFFÜHRUNG/ BETRAGEN - GUTER WIRT

SPECIFIC FAULTS/ MISTAKES: DRUNK, GAMBLER, GETS INTO DEBTS, ARSONIST, SELFISH I FEHLER: DEM TRUNK ERGEBEN, SPIELER, SCHULDENMACHER, ZÜNDER, EIGENNÜTZIG CONDUCT/BEHAVIOUR MISTAKES / AUFFÜHRUNG/ BETRAGEN - FEHLERN UNTERWORFEN

OTHER OBSERVATIONS / SONST IM DIENST

DESERVES THE ADVANCEMENT / VERDIENT DAS AVANCEMENT

OTHER INFORMATION / SONSTIGE ANMERKUNGEN

RIDER / REITER. Checkbox should be ticked if applicable.

HIPPOLOGIST / PFERDKENNER. Checkbox should be ticked if applicable.

SOURCE I QUELLE. The source will be selected from the drop down list (table 'Sources / Quellen'). If it does not feature in the respective table, it can be added manually. As a rule of thumb, each new source's entry in the table 'Sources / Quellen' should always be made before recording any information from the respective source into the database.

REMARKS / ANMERKUNGEN. Same as for the previously detailed tables. 
Figure 6. Sample information from the table 'Lists of conduct' (view mode) ${ }^{12}$

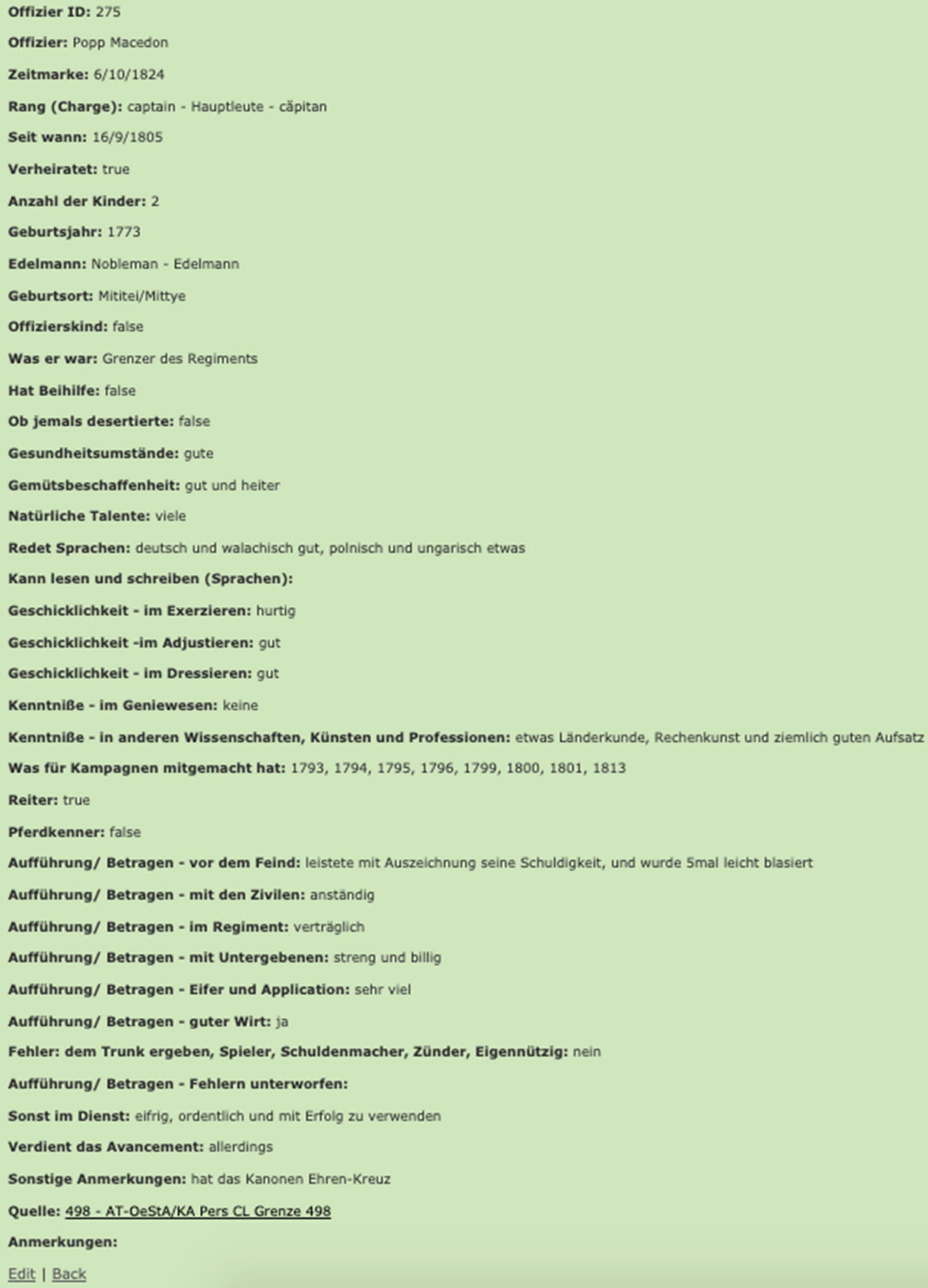

${ }^{12}$ http://82.208.133.141:3020/mconducts/1. 


\section{Table 'CAREERS / KARRIEREN'}

This table represents an extension of the table 'List of conduct / Konduitenliste' dedicated to accommodating information on the officer's careers. Due to the particular way in which the lists of conduct - and army documents in general - recorded the latter (see the table below), and due also to the high differences in length between careers of different officers, the best technical solution was to develop a distinct table, suitable for this pattern of regressive chronological registering.

Table 1. Recording style of the officer's careers

\begin{tabular}{llll}
\hline Position 1 (the oldest) & no. of years & no. of months & no. of days \\
\hline Position 2 & no. of years & no. of months & no. of days \\
\hline Position 'n' (preceding the current position) & no. of years & no. of months & no. of days \\
\hline
\end{tabular}

Figure 7. Officer career as recorded in the lists of conduct ${ }^{13}$

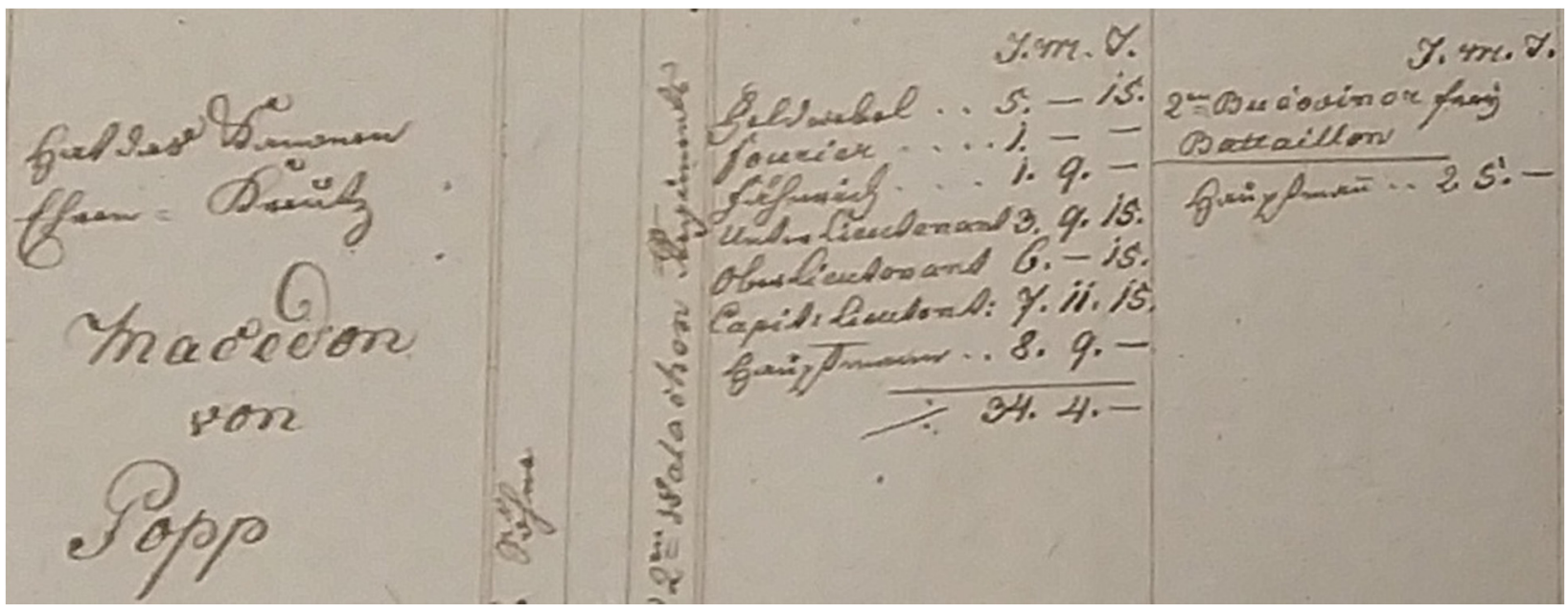

Figure 8. Same career as recorded in the database ${ }^{14}$

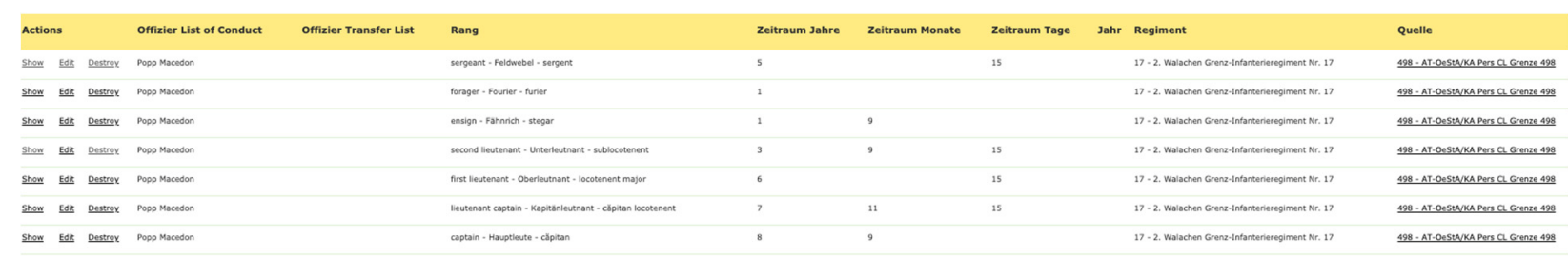

13 (Partial) List of conduct of captain Macedon von Popp of the Border Guard Regiment no. 17 from Năsăud (Romanian no. 2), 1824. AT-OeStA/ KA Pers CL Grenze 498, Grenzinfanterieregiment Nr. 16 (1824-1849), Grenzinfanterieregiment Nr. 17 (1824-1840).

http://82.208.133.141:3020/mbcareers?q\%5Bmconduct_mbindividual_lastname_or_mconduct_mbindividual_fir stname or_mconduct mbindividual_nickname_or_mbtransfer_list_mbindividual_lastname_or_mbtransfer_list mbindividual_firstname or_mbtransfer_list_mbindividual_nickname cont $\% 5 \mathrm{D}=\bar{p}$ popp $\&$ commit $=$ Search

Studia UBB Digitalia, Volume 64 (XLIV), 2019, December, Issue 2 
In the current form, each new entry in the table 'Careers / Karrieren' represents a stage in an officer's career, and the whole career can be recreated / visualized by following the string of entries for each person / ID.

OFFICER FROM LIST OF CONDUCT/ OFFIZIER AUS KONDUITENLISTE The respective officer is selected from the drop down menu linked to the table 'List of conduct / Konduitenliste'.

OFFICER FROM LIST OF TRANSFER/ OFFIZIER AUS TRANSFERIERUNGSLISTE The respective officer is selected from the drop down menu linked to the table 'List of transfer / Transferierungsliste'.

PERIOD YEARS / ZEITRAUM JAHRE. To be filled in according to the source.

PERIOD MONTHS / ZEITRAUM MONATE. To be filled in according to the source.

PERIOD DAYS / ZEITRAUM TAGE. To be filled in according to the source.

YEAR / JAHR. To be filled in according to the source.

UNIT / REGIMENT. Same as for the previously detailed tables.

SOURCE / QUELLE. Same as for the previously detailed tables.

REMARKS / ANMERKUNGEN. Same as for the previously detailed tables.

The following three tables (5-7) cover the summary page of the monthly tables of the military personnel (see above 4.a. Military monthly tables / Monatstabellen Militär, and Figure 1). As already mentioned, this type of document contains both nominal and statistical information, thus being extremely difficult to accommodate in a single form. To this, structural differences from regiment to regiment, or depending on the chronological period, should be added. Among the latter, the most important ones refer to the mention or not of border pickets, as well as the reasons for the absence or presence of staff (i.e., in one regiment the number of returned deserters may be mentioned in a separate heading, while in another regiment they may be counted together with other categories of soldiers returning from leave).

Given the above, the monthly tables of the military personnel were structured, within the database, in three main tables, one of which accommodates the nominative information, and the other two, of EAV type, accommodate the statistics. The original document can be recreated at any time by concatenating these three main tables and the adjacent secondary tables. Given the nature and structure of the source, the information pertaining to all three tables can be easily extracted in preformatted spreadsheets in order to be latter imported in the database. 


\section{Table 'MONTHLY TABLE MILITARY NOMINAL / MONATSTABELLE MILITÄR NOMINELL'}

In the current form, each new entry in the table records information about an officer, and the Regimental Staff and officers' corps can be recreated by joining the entries linked to the same source.

COMPANY I KOMPAGNIE. The subdivision of the regiment (company or Regimental Staff) to which the respective officer is assigned will be selected from a dropdown menu (Table 'Companies / Kompagnien). If it does not feature in the respective table, it should be first added there manually. Subdivisions are registered in the dedicated dropdown table already linked to their main unit of belonging (e.g. regiment).

OFFICER / OFFIZIER. Same as for the table 'List of conduct / Konduitenliste'.

NOBILITY I ADELSSTAND. Same as for the table 'List of conduct / Konduitenliste'.

VOLUNTEER/DRAFTED / (UN)OBLIGAT. To be selected from the dropdown list (table 'Volunteer / Freiwilligkeit'. If it does not feature in the respective table, it should be first added there manually.

STATE I ZUSTAND. To be selected from the dropdown list (table 'State / Zustand'). If it does not feature in the respective table, it should be first added there manually.

START DATE I ANFANGSDATUM. To be filled in according to the source.

END DATE / ENDDATUM. To be filled in according to the source.

SOURCE / QUELLE. Same as for the previously detailed tables.

REMARKS / ANMERKUNGEN. Same as for the previously detailed tables.

\section{Table 'MONTHLY TABLE MILITARY STATISTICS - RANKS I MONATSTABELLE MILITÄR STATISTIK - RANGORDNUNG'}

This table registers the number of militaries of a certain rank in each subunit for the month under scrutiny. The full strength of the subunit (and further on of the main unit), in statistical terms, can be recreated by joining the entries for the respective ranks within the same source.

COMPANY I KOMPANIE. Same as for the previous table.

TIMESTAMP / TIMESTAMP. Same as for the table 'List of conduct / Konduitenliste'. 
RANK / RANG. Same as for the previously detailed tables. In this case, the rank does not refer to a specific person, but functions as a header for counting how many militaries of each rank are registered in the respective unit or subunit during the period under scrutiny.

VALUE / ZIFFER. To be filled in according to the source.

SOURCE / QUELLE. Same as for the previously detailed tables.

REMARKS / ANMERKUNGEN. Same as for the previously detailed tables.

\section{Table 'MONTHLY TABLE MILITARY STATISTICS - IN-OUT I MONATSTABELLE MILITÄR STATISTIK - IN-OUT'}

This table registers the personnel movement within each subunit, and respectively the whole regiment, for the month under scrutiny. Each entry represents a type of personnel movement and the associated statistical figures.

COMPANY / KOMPAGNIE. Same as for the previous table.

TIMESTAMP / ZEITMARKE. Same as for the table 'List of conduct / Konduitenliste'.

ATTRIBUTE/FLOW TYPE / MERKMAL/BEWEGUNG. To be selected from the dropdown list (table 'Personnel flow / Zuwachs und Abgang des Personals'). If it does not feature in the respective table, it should be first added there manually. Attributes can pertain to either the officer's corps or to the NCOs and the troop, each of these two sections featuring on a distinct side of the document. In order to choose the correct reference, the following dropdown list should be used.

CATEGORY I RUBRIK. This is a value list differentiating between the two above mentioned sections of the personnel movement - to be chosen accordingly.

VALUE / ZIFFER. To be filled in according to the source.

SOURCE / QUELLE. Same as for the previously detailed tables.

REMARKS / ANMERKUNGEN. Same as for the previously detailed tables.

The monthly tables of the administrative personnel have risen less difficulties, but still, due to the dual nature of the information they encompass (nominal and statistical, see above Figure 2) they had to be split in two distinct forms, detailed below. Given the nature and structure of the source, the information pertaining to both tables can be easily extracted in preformatted spreadsheets in order to be latter imported in the database. 


\section{Table 'MONTHLY TABLE ADMINISTRATION NOMINAL / MONATSTABELLE VERWALTUNG NOMINELL'}

REGIMENT / REGIMENT. To be selected from the dropdown list (table 'Regiment / Regiment'). If it does not feature in the respective table, it should be first added there manually.

POSITION IN DEPARTMENT / STELLE IN DER BRANCHE. To be selected from the dropdown list (table 'Positions / Stellen'). If it does not feature in the respective table, it should be first added there manually.

STAFF I BEAMTEN. To be selected from the drop down list (table 'Individuals / Personen'). Same rules apply as for the officers - see above table 'List of conduct / Konduitenliste'.

START DATE I ANFANGSDATUM. To be filled in according to the source.

END DATE / ENDDATUM. To be filled in according to the source.

SOURCE I QUELLE. Same as for the previously detailed tables.

REMARKS / ANMERKUNGEN. Same as for the previously detailed tables.

\section{Table 'MONTHLY TABLE ADMINISTRATION STATISTICS I MONATSTABELLE VERWALTUNG STATISTIK.'}

REGIMENT / REGIMENT. Same as for the previously detailed table.

POSITION IN DEPARTMENT / STELLE IN DER BRANCHE. Same as for the previously detailed table. In this case it does not refer to a specific individual, but functions as a header for counting how many persons occupy a given position for the month under scrutiny.

NO. OF STAFF I ANZAHL DER BEAMTEN. To be filled in according to the source.

START DATE I ANFANGSDATUM. To be filled in according to the source.

END DATE / ENDDATUM. To be filled in according to the source.

SOURCE / QUELLE. Same as for the previously detailed tables.

REMARKS / ANMERKUNGEN. Same as for the previously detailed tables. 


\section{Table 'SALARIES ADMINISTRATIVES BRANCHES / VERWAVALTUNGS- BESOLDUNGS-ENTWÜRFE'}

This table registers the salary paid to each administrative employee of the regiment for a given month, as well as all the financial details related to this operation.

STAFF I BEAMTEN. To be selected from the drop down list (table 'Individuals / Personen'). Same rules apply as for the officers - see above table 'List of conduct / Konduitenliste'.

REGIMENT / REGIMENT. Same as for the previously detailed table.

POSITION IN DEPARTMENT / STELLE IN DER BRANCHE. Same as for the previously detailed table.

START DATE I ANFANGSDATUM. To be filled in according to the source.

END DATE / ENDDATUM. To be filled in according to the source.

EMPLOYMENT DATE I DATUM DER ANSTELLUNG. To be filled in according to the source.

EMPLOYMENT SITE I ANSTELLUNGSORT. The information under the respective column header will be transcribed exactly as recorded in the source. See also above: 6.a. General principles. Due to the fact that the information under this header did not always refer to localities, we have chosen not to normalize this field.

MONTHLY WAGE I MONATLICHER GEHALT. To be filled in according to the source.

HEREFROM TAX / HIERVON KLASSENSTEUER. To be filled in according to the source.

HEREFROM 2 1/2 PERCENT TAX / HIERVON AN 2 u. $1 / 2$ PROZENTIG KLASSENSTEUER. To be filled in according to the source.

HEREFROM 5 PERCENT DEPOSIT I HIERVON AN 5 PROZENTIG ARRHA. To be filled in according to the source.

HENCE CASH 7 1/2 PERCENT IN CONVENTIONAL COIN / MITHIN BAR AN 7 u. 1/2 PROZENTIG CONVENTIONS-MÜNZE. To be filled in according to the source.

HENCE CASH IN BANKNOTE AND COIN/CASH I MITHIN BAR AN BANKOZETTEL UND SCHEIDEMÜNZE/BAR. To be filled in according to the source. 
SOURCE / QUELLE. Same as for the previously detailed tables.

SOURCE REMARKS / ANMERKUNGEN. Same as for the previously detailed tables.

11. Table 'MUSTER ROLL / MUSTERLISTE' (see also above Figure 3)

OFFICER / OFFIZIER. Same as for the previously detailed tables.

TIMESTAMP (DOCUMENT DATE) / ZEITMARKE (DATUM DER UNTERLAGE). TO be filled in according to the source.

REGIMENT / REGIMENT. Same as for the previously detailed tables.

PREVIOUS CAREER I BISHERIGE KARRIERE. The information under the respective column header will be transcribed exactly as recorded in the source. See also above: 6.a. General principles. Information in this field will require further normalization in order to be subjected to serial analyses.

LAND OF ORIGIN / LAND. The information under the respective column header will be transcribed exactly as recorded in the source. See also above: 6.a. General principles. Due to the typological diversity of the information in the sources, this field has not been associated with the dropdown of the table 'Localities / Orte'.

BORDER COMMUNITY I GRENZE. To be filled in according to the source. Same situation as for the field LAND OF ORIGIN / LAND.

HOUSE NO. I HAUSNUMMER. To be filled in according to the source.

WEARS THE DISTINCTION ARMY CROSS I TRÄGT DAS ARMEEKREUZ. Checkbox should be ticked if applicable.

EXTRA-REINLISTEE (VOLUNTARILY LONGER SERVING SOLDIER) I EXTRANEIS-KAPITULANTEN. Checkbox should be ticked if applicable.

EXTRA-HAS THE DISTINCTION BETWEEN 1ST AND 2ND CLASS / EXTRANEISDISTINCTION ZWISCHEN 1. UND 2. KLASSE. The appropriate class should be chosen, if applicable.

AGE YEARS / ALTER JAHRE. To be filled in according to the source.

AGE MONTHS-DAYS / ALTER MONATE-TAGE. To be filled in according to the source.

CHILDREN / KINDER. Checkbox should be ticked if applicable. 
SOURCE / QUELLE. Same as for the previously detailed tables.

SOURCE REMARKS / ANMERKUNGEN. Same as for the previously detailed tables.

\section{Table 'REVISION LIST / REVISIONSLISTE'}

OFFICER / OFFIZIER. Same as for the previously detailed tables.

TIMESTAMP (DOCUMENT DATE) / ZEITMARKE (DATUM DER UNTERLAGE). TO be filled in according to the source.

REGIMENT / REGIMENT. Same as for the previously detailed tables.

SOURCE REMARKS I ANMERKUNGEN. To be filled in according to the source.

HOUSE NO. I HAUSNUMMER. To be filled in according to the source.

RECEIVED MEDALS OR THE ARMY CROSS / BETEILT MIT MEDAILLEN ODER ARMEEKREUZ. Checkbox should be ticked if applicable.

RECEIVED THE VETERAN DISTINCTION 1ST/2ND CLASS I BETEILT MIT VETERANEN-ZEICHEN 1. KLASSE/2. KLASSE. The appropriate class should be chosen, if applicable.

MARRIED / VERHEIRATET. Checkbox should be ticked if applicable.

CHILDREN - MALE / KINDER - MÄNNLICH. The number of male children should be filled in, according to the source.

CHILDREN - FEMALE / KINDER - WEIBLICH. The number of female children should be filled in, according to the source.

SOURCE / QUELLE. Same as for the previously detailed tables.

13. Table 'NOMINAL ROLL / NOMINALISTE'

OFFIZIER / OFFIZIER. Same as for the previously detailed tables.

ZEITMARKE (DATUM DER UNTERLAGE) I ZEITMARKE (DATUM DER UNTERLAGE). To be filled in according to the source.

REGIMENT / REGIMENT. Same as for the previously detailed tables.

QUELLE / QUELLE. Same as for the previously detailed tables. 
SOURCE REMARKS / ANMERKUNGEN. Same as for the previously detailed tables.

\section{Table 'RECRUITMENT LIST I ASSENTLISTE'}

OFFICER / OFFIZIER. Same as for the previously detailed tables.

TIMESTAMP (DOCUMENT DATE) / ZEITMARKE (DATUM DER UNTERLAGE). TO be filled in according to the source.

REGIMENT / REGIMENT. Same as for the previously detailed tables.

COMPANY / KOMPAGNIE. Same as for the previously detailed tables.

LAND OF ORIGIN / LAND. The information under the respective column header will be transcribed exactly as recorded in the source. See also above: 6.a. General principles.

AGE YEARS / ALTER JAHRE. To be filled in according to the source.

AGE MONTHS-DAYS / ALTER MONATE-TAGE. To be filled in according to the source.

WHERE DID HE SERVED PREVIOUSLY / HAT VORHER GEDIENT. The information under the respective column header will be transcribed exactly as recorded in the source. See also above: 6.a. General principles.

DATE OF EXAMINATION/ ACCEPTANCE / DATUM DER ASSENTIERUNG. To be filled in according to the source.

PHYSICIAN / ARZT. To be selected from the table 'Individuals / Personen'. Same rules apply as for officers and administrative personnel.

SOURCE / QUELLE. To be filled in according to the source.

15. Table ‘LIST OF ENROLLMENT / ENROLLIRUNGSLISTE

OFFICER / OFFIZIER. Same as for the previously detailed tables.

TIMESTAMP (DOCUMENT DATE) / ZEITMARKE (DATUM DER UNTERLAGE). TO be filled in according to the source.

REGIMENT / REGIMENT. Same as for the previously detailed tables.

COMPANY / KOMPAGNIE. Same as for the previously detailed tables. 
LAND OF ORIGIN / LAND. The information under the respective column header will be transcribed exactly as recorded in the source. See also above: 6.a. General principles.

AGE YEARS / ALTER JAHRE. To be filled in according to the source.

AGE MONTHS-DAYS I ALTER MONATE-TAGE. To be filled in according to the source.

DATE OF ENROLMENT I DATUM DER ENROLLIERUNG. To be filled in according to the source.

SOURCE / QUELLE. Same as for the previously detailed tables.

\section{Table 'LIST OF TRANSFER / TRANSFERIERUNGSLISTE'}

The lists of transfer usually include a description, more or less narrative, of the officer's career. The respective information should be inputted into the table 'Careers/ Karrieren' and the respective entries will be linked to the transfer list by selecting the appropriate officer's name.

OFFICER / OFFIZIER. Same as for the previously detailed tables.

TIMESTAMP (DOCUMENT DATE) / ZEITMARKE (DATUM DER UNTERLAGE). To be filled in according to the source.

DATE OF (DECISION OF) TRANSFER / ZEITMARKE (DATUM DER UNTERLAGE). To be filled in according to the source.

TRANSFERRED FROM (COMPANY) / VON (KOMPAGNIE). The company of origin will be chosen from the dropdown menu (Table 'Company / Kompagnien), same as for the previously detailed tables.

TRANSFERRED FROM / VON. The main unit of origin will be selected from the dropdown list (table 'Regiment / Regiment'), same as for the previously detailed tables.

TRANSFERRED TO (COMPANY) / ZU (KOMPAGNIE). The company in which was transferred will be chosen from the dropdown menu (Table 'Company / Kompagnien), same as for the previously detailed tables,

TRANSFERRED TO / ZU. The main unit in which was transferred will be selected from the dropdown list (table 'Regiment / Regiment'), same as for the previously detailed tables. 
PREVIOUS CAREER I BISHERIGE KARRIERE. This field records the information about careers which cannot be otherwise registered in the dedicated table ('Careers / Karrieren'). The information under the respective column header will be transcribed exactly as recorded in the source. See also above: 6.a. General principles. Information in this field will require further normalization in order to be subjected to serial analyses.

LAND OF ORIGIN / LAND. The information under the respective column header will be transcribed exactly as recorded in the source. See also above: 6.a. General principles.

AGE YEARS / ALTER JAHRE. To be filled in according to the source.

AGE MONTHS-DAYS / ALTER MONATE-TAGE. To be filled in according to the source.

CHILDREN - MALE / KINDER - MÄNNLICH. The number of male children should be filled in, according to the source.

CHILDREN - FEMALE / KINDER - WEIBLICH. The number of female children should be filled in, according to the source.

RECRUITMENT DATE I DATUM DER ASSENTIERUNG. To be filled in according to the source.

For the following fields, the information under the respective column header will be transcribed exactly as recorded in the source. See also above: 6.a. General principles:

ENLISTED WITH OR WITHOUT CONTRACT I MIT ODER OHNE CAPITULATION ANGEWORBEN WORDEN

IF HE EVER DESERTED, WAS PART OF A PLOT OR WAS TAKEN PRISONER I OB JEMALS DESERTIERTE, IN EINEM KOMPLOTT VERFANGEN GEWESEN ODER IN KRIEGSGEFANGENSCHAFT GERATEN

WHEN AND HOW HE RETURNED FROM CAPTIVITY I WANN UND WIE IST AUS DER KRIEGSGEFANGENSCHAFT ZURÜCKGEKOMMEN

DEFECTS AND INJURIES / DEFEKTE UND BLESSUREN

MERIT AND CONDUCT / VERDIENST UND KONDUITE

ON LEAVE SINCE / BEURLABT SEIT

HOW OFTEN AND WHEN HAS HE RECEIVED HOLIDAY GRATUITIES / WIE OFT UND WANN HAT DAS URLAUBS-DOUCEUR MIT 6 GULDEN EMPFANGEN

RECEIVED UNIFORM PIECES AND TAKES FOLLOWING WITH HIMSELF / NIMMT AN MONTURSORTEN MIT SICH UND WELCHE RECEIVED SOLDIER'S SHOE ALLOWANCE / NIMMT AN SOHLENGELD 
SOURCE / QUELLE. Same as for the previously detailed tables.

SOURCE REMARKS / ANMERKUNGEN. Same as for the previously detailed tables.

\section{Table 'LIST OF RETURNED DESERTERS / PRÄSENTIRUNGSLISTE'}

OFFICER / OFFIZIER. Same as for the previously detailed tables.

TIMESTAMP (DOCUMENT DATE) / ZEITMARKE (DATUM DER UNTERLAGE). TO be filled in according to the source.

REGIMENT / REGIMENT. Same as for the previously detailed tables.

COMPANY I KOMPAGNIE. Same as for the previously detailed tables.

LAND OF ORIGIN / LAND. The information under the respective column header will be transcribed exactly as recorded in the source. See also above: 6.a. General principles.

AGE YEARS / ALTER JAHRE. To be filled in according to the source.

AGE MONTHS-DAYS I ALTER MONATE-TAGE. To be filled in according to the source.

For the following fields, the information under the respective column header will be transcribed exactly as recorded in the source. See also above: 6.a. General principles:

WAS TRAINED AS / IST DABEI ZUGEWACHSEN

WHERE DID HE SERVED PREVIOUSLY I HAT VORHER GEDIENT

DESERTED FROM HIS REGIMENT / DESERTIERT VOM REGIMENT

EQUIPMENT TAKEN / MONTUR UND RÜSTUNG MITGENOMMEN

REASON FOR DESERTING / URSACHE DER DESERTION

IN THE MEANTIME LIVED IN / INZWISCHEN AUFGEHALTEN

RETURNED FROM WHICH PLACE / WOVON ZURÜCKGEKOMMEN (ORT)

EQUIPMENT BROUGHT BACK / MONTUR UND RÜSTUNG MITGEBRACHT

SOURCE / QUELLE. Same as for the previously detailed tables.

\section{Table 'MEDICAL CERTIFICATE / ÄRZTLICHES ZEUGNIS'}

OFFICER / OFFIZIER. Same as for the previously detailed tables.

REGIMENT / REGIMENT. Same as for the previously detailed tables. 
DATE I DATUM DER UNTERLAGE. To be filled in according to the source.

MEDICAL CERTIFICATE I ÄRZTLICHES ZEUGNIS. The information under the respective column header will be transcribed exactly as recorded in the source. See also above: 6.a. General principles.

PHYSICIAN / ARZT. Same as for the previously detailed tables.

SOURCE / QUELLE. Same as for the previously detailed tables.

SOURCE REMARKS I ANMERKUNGEN. Same as for the previously detailed tables.

Figure 9. Medical certificate of private-fusilier loan Kottul of the Border Guard Regiment no. 17 from Năsăud (Romanian no. 2), $5^{\text {th }}$ Company, September $22^{\text {nd }}, 1842^{15}$

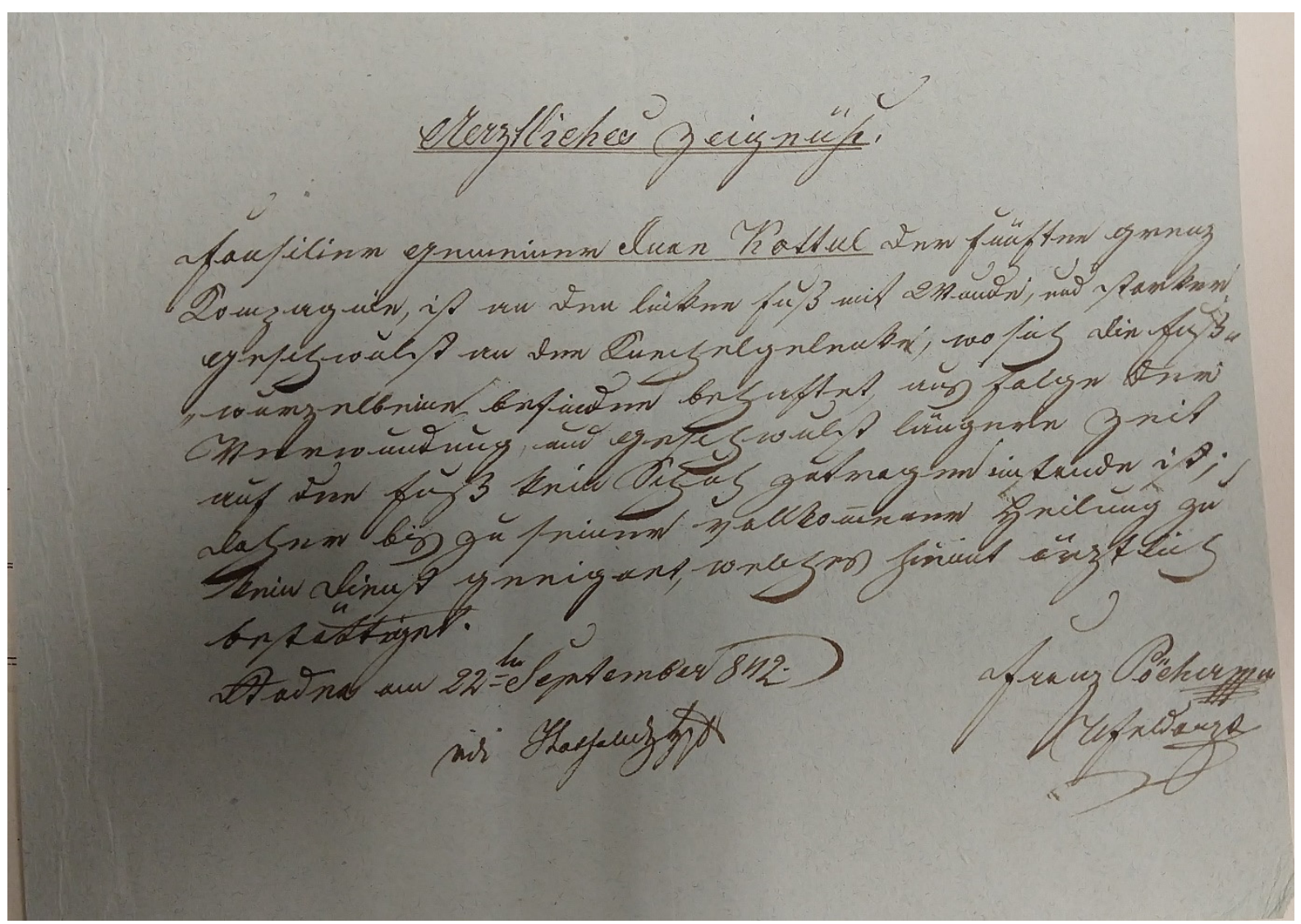

${ }^{15}$ AT-OeStA/ KA Pers MLST I GIR 17 6175, Revisionslisten, Nominal-Lista (1834-1846). 
Figure 10. Database view of the information in the medical certificate from Figure $9^{16}$

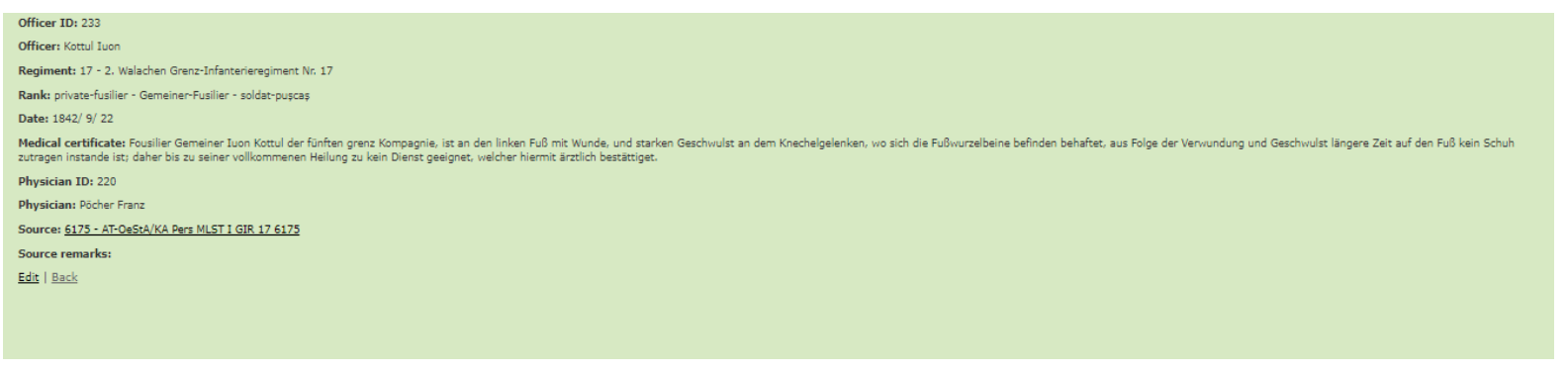

\section{Table 'UNITS / ARMEEKORPS'}

This normalization table records the main autonomous military units (i.e. regiments, battalions), but also army units functioning as an institution (e.g. military hospitals). It also provides the Romanian translation of the terms in German and English (and other normalization tables do the same), in order to promote the database among Romanian users and support the use of a standardized translation terminology. It consists of the following fields:

UNIT NO. / REGIMENTSNUMMER

UNIT NAME / NAME DER HEERESEINHEIT

UNIT NAME EN / NAME DER HEERESEINHEIT EN

UNIT NAME RO / NAME DER HEERESEINHEIT RO

START DATE / ANFANGSDATUM

END DATE / ENDDATUM

REMARKS / ANMERKUNGEN.

\section{Table 'COMPANIES / KOMPAGNIEN'}

This normalization table records subunits within the main military units (i.e. companies), together with other subdivisions (e.g. Regimental Staff, Supernumeraries). It should be noted that companies were not necessarily assigned a number, instead they were frequently identified by the name of their commanding officer, or by the location of the command center. The entry-form consists of the following fields:

REGIMENT / REGIMENT

COMPANY NAME / NAME DER KOMPAGNIE

COMPANY NUMBER / NUMMER

COMPANY COMMAND CENTRE / HAUPTORT DER KOMPAGNIE

START DATE / ANFANGSDATUM

END DATE / ENDDATUM

${ }^{16} \mathrm{http}: / / 82.208 .133 .141: 3020 /$ mbmedical_certificates/11. 


\section{Table 'PERSONNEL FLOW / ZUWACHS UND ABGANG DES PERSONALS'}

This table records various instances of personnel movement mentioned in the documents. It functions as a support table for the statistical information provided by the monthly tables of the military personnel. It currently includes 41 such instances, whose full list is detailed below with the sole aim of illustrating the variety of information hosted by the documents:

1. inflow-transferred in regiment / Zuwachs-Im Regiment transferiert

2. inflow-transferred in battalion / Zuwachs-Im Bataillon transferiert

3. inflow-from supernumeraries / Zuwachs-Von den Supernumerarien

4. inflow-from other regiments and troops / Zuwachs-Von anderen Regimentern und Korps

5. inflow-from other companies / Zuwachs-Von anderen Kompagnien

6. inflow-returned deserters / Zuwachs-Revertierte/ Zurückgelangte Deserteure

7. inflow-returned from captivity / Zuwachs-Aus der Kriegsgefangenschaft zurückgekommen

8. inflow-from disbanded frontiersmen / Zuwachs-Von übrigen Grenzstand

9. inflow-newly enrolled / Zuwachs-Von Neuen/ Neu coscribiert/ Neu enroulliert/ Neu assentiert

10. inflow-newly replaced / Zuwachs-Neu ersetzt

11. inflow-mistakenly registered in "outflow" / Zuwachs-Per errorem in Abgang

12. outflow-transferred to other regiments and troops / Abgang-Zu anderen Regimentern und Korps transferiert

13. outflow-transferred to other companies / Abgang-Zu anderen Kompagnien

14. outflow-transferred in regiment / Abgang-Im Regiment transferiert

15. outflow-transferred in battalion / Abgang-Im Bataillon transferiert

16. outflow-to supernumeraries / Abgang-Zu Supernumerariern

17. outflow-transferred to canton / Abgang-Zum Kanton transferiert

18. outflow-to the field departments / Abgang-Zu den in feldstehenden Abteilungen

19. outflow-deserters / Abgang-Desertiert

20. outflow-executed / Abgang-Justifiziert

21. outflow-unaccounted for / Abgang-Vermisst

22. outflow-demobilised / Abgang-aus dem Dienststande geschrieben/ Ausroulliert

23. outflow- disbanded frontiersmen / Abgang-Zu dem übrigen Grenzstand

24. outflow-deceased / Abgang-Gestorben

25. outflow-dismissed / Abgang-Entlassen

26. outflow-retired / Abgang- In Pension Stand

27. outflow-pardoned thieves, unworthy of military service, who are now transferred to the civil service / Abgang-unwürdig zum Miliär Stand als pardonierte Räuber dem Camerali übergeben 
28. outflow-mistakenly registered in "inflow" / Abgang-Per errorem Zuwachs

29. in command / Kommandiert

30. in command of sentinels in the mountains / Kommandiert-auf Plajen Wacht

31. in command of staff's watch / Kommandiert-auf Stabswacht

32. in command of guardhouses/ watching stations and sentinels / Kommandiert-auf Postirung und Plajen

33. in command of postal couriers / Kommandiert-auf Brief Odonanz

34. in command of staff and postal couriers / Kommandiert-auf Stab und Brief Odonanz

35. in command-special command / Kommandiert- extra Kommando

36. in command and absent / Kommandiert und Absent

37. in command and absent-with external rations / Kommandiert und Absentmit auswärtiger Verpflegung

38. in command and absent-with internal rations / Kommandiert und Absentmit Loco Verpflegung

39. on leave / Beurlaubt

40. sick / Kranke

41. sick in local hospital / Kranke in Loco Spital

The entry-form consists of the following fields:

\section{CATEGORY EN / RUBRIK EN \\ CATEGORY DE / RUBRIK DE \\ CATEGORY RO / RUBRIK RO \\ REMARKS / ANMERKUNGEN}

\section{Table 'RANKS \& ROLES / RÄNGE \& STELLEN'}

This table details the military ranks of the Austrian army, but also a variety of specific military and administrative positions featured in the documents. It currently includes 136 ranks and roles / positions within the military milieu, and it is far from claiming full coverage. It consists of the following fields:

\section{RANK/ROLE EN / RANG/STELLE EN RANK/ROLE DE / RANG/STELLE DE RANK/ROLE RO / RANG/STELLE RO RANK/ROLE HU / RANG/STELLE HU REMARKS / ANMERKUNGEN}

\section{Table 'DEPARTMENT / BRANCHEN'}

This table lists the border regiments' departments mentioned in the monthly administrative overviews. Currently there are only six such departments recorded: Forest / Wald; School / Schule; Special staff / Extra Personal; Clergy / Geistlichkeit; 
Commercial streets / Kommerzialstraßen; Paper production (papermill) / Papiermachen.

A generic recording, titled General list of professions / Allgemeine Liste der Berufe, supports the registration of professions in the table 'Positions / Stellen'.

The form consists of only two fields:

\section{TITLE EN / TITEL EN} TITLE DE / TITEL DE

\section{Table 'POSITIONS / STELLEN'}

This table details the professions pertaining to the above mentioned departments. Currently, there are 25 registered professions. The form consists of only three fields:

\section{DEPARTMENT / BRANCHE \\ POSITION / STELLE \\ REMARKS / ANMERKUNGEN}

\section{Table 'COUNTIES / KOMITATE}

This table aids with the normalization of the locations by means of a list of the main administrative units of the time: the counties / Komitaten. The form currently consists of only one field, recording the name of the county. In the future, we aim at developing it by providing translations of the county names in all the main languages of the time.

\section{Table 'DISTRICTS / BEZIRKE’}

The district was a sub-division of the county. This table details the districts in Transylvania, thus aiding in placing a specific locality within its administrative chain. The form currently consists of only one field, recording the name of the district.

\section{Table 'LOCALITIES / ORTE'}

This table provides a list of all the localities in Transylvania and also allows the recording of new ones, to which the sources might refer (e.g. localities from outside the province, or even from outside the monarchy). It consists of the following fields:

COUNTY I KOMITAT. To be selected from the dropdown list and the dedicated table. DISTRICT / BEZIRK. To be selected from the dropdown list and the dedicated table.

OLD HUNGARIAN NAME I ALTE UNGARISCHE BEZEICHNUNG NEW HUNGARIAN NAME / NEUE UNGARISCHE BEZEICHNUNG GERMAN NAME / DEUTSCHER NAME CURRENT NAME / AKTUELLER NAME 


\section{Table 'STATE / ZUSTAND'}

This support table refers to the situation of an officer in relation to its position: present, absent, or in command. It consists of only one field (STATE I ZUSTAND), registering these three possibilities.

\section{Table 'VOLUNTEERING / FREIWILLIGKEIT'}

This support table refers to the way in which a person has entered the army, namely as a volunteer, or drafted. It consists of only one field (SITUATION I SITUATION), registering these two possibilities.

\section{Table 'NOBILITY I ADELSTAND'}

This support table provides a list of nobility titles mentioned in the documents. The form consists of three fields:

\section{TITLE EN / TITEL EN} TITLE DE / TITEL DE

\section{REMARKS / ANMERKUNGEN}

\section{Table 'SOURCES / QUELLEN'}

This table provides the means of referencing the information in the database, by listing the archival sources used and details about their physical location. The form consists of four fields:

\section{ARCHIVAL UNIT CALL NO. I KARTON/FASZIKEL ARCHIVAL UNIT DESCRIPTION / SIGNATUR CATALOGUE LINK / LINK REMARKS / ANMERKUNGEN}

\section{Limitations of the current version}

\section{a. Geographic, chronologic and typological coverage}

The sources that we have listed and described above (sections 4 and 6) make up only a part of the documents through which the records of the entire Austrian army were kept, in particular those drafted for the border guard regiments. Although we have focused for now on the regiments from the Transylvanian and the Banat border, the typology of the mentioned sources is similar, to a certain degree, to the entire Habsburg military border, and the structure of these documents is extremely similar as well. Nevertheless, they are not, unfortunately, sufficiently standardized so that the database, in its current form, developed for Transylvania and the Banat, to be able to completely accommodate information from other regions of the monarchy.

Initially, we have hoped that the documents for the Croatian and for the Transylvanian military border areas would be identical in structure. Two short 
documentation stages at the War Archive in Vienna have been enough to prove that there are structural differences not only between the documents issued in different regions of the military border, but also between different regiments and even within the same regiment, at a distance of several decades. For example, although they mainly contain the same type of information, the monthly tables of the Croatian regiments are not fully identical to those of Transylvanian regiments, while those of the Regiment no. 17 in Năsăud from 1763 /64 are not identical to those issued by the same unit in 1805.

This signifies that, while a large part of the information from the primary sources can be accommodated and compared irrespective of the region or period it refers to, there is also a high chance that for each different region and for different time periods, new forms, new fields and new types of relations should be created. The database, in its current form, is thus only a perfectible and extensible tool, that can be adapted to the research requirements of potential users.

\section{b. The level of normalization of the information from primary sources}

As we have mentioned in section 5. General principles of constructing the database and as it is clearly evidenced in section 6. Table structure and data introduction manual, in its actual form, the Digital Framework for the History of the Austrian Military Border in Transylvania implies a level of normalization higher than the one suggested by the state of the art on best practices in constructing historical databases. The objective and subjective reasons supporting our option have been already stated throughout the paper. We would only underline here the fact, already mentioned at the end of section 5, that in the current form, the database can still be used for registering multiple terminological variations from the sources, if the specifics of the research require it, and the logistics allow it.

\section{c. Public access, filters and search engine}

In the current version, the database provides the public user with only one search filter (person name), which allows the identification of the information from all source-oriented tables connected to the main normalization table ('Individuals I Personen'). The search returns all the matches of the respective string in these tables, but it only shows a selection of columns.

Registered users have access to several search filters, yet still few in numbers - usually a name filter for each table hosting nominal data and timestamp filters for the tables detailing the lists of conduct, military and administrative personnel. The main reasons for which only a limited selection of search filters is available has to do with the few information inputted in the database to this moment. We have focused on building the digital instrument and not on populating it with information. Their main purpose is to help testing the database functionality and have less to do with data extraction for historical research purposes. The following version of the database will include more filters for both types of users, a wider selection of columns from the source-oriented tables and the possibility of downloading the search results in .csv 
and spreadsheet formats for registered users. Our intention is to make available a database with full open access, however this aim is conditioned by obtaining funding for transcription and data input as well as for the technical finishing touches.

\section{Conclusions}

The Digital Framework for the History of the Austrian Military Border in Transylvania originated in two generous, intertwined, ideas: to provide a state of the art tool which would help the Romanian historical writing on the topic overcome petty localism by reconnecting it with the primary sources, and to build a database which could aggregate information for the whole Austrian military border, paving the way towards cooperation and integrated research on the topic.

The database suits very well the first of the aforementioned aims, by accommodating the main type of documents issued by the border regiments in Transylvania and the Banat. Its structure allows the input of data from basically any such document, and the small amount of information currently in the database, entered for testing reasons only, can be at any times expanded without requiring major alterations of the current version.

Although it was designed as a tool for specific parts of the former military border that are now on Romanian territory, its bilingual interface (English and German) ensures a wider usage. Moreover, the current version provides translations in English, German and Romanian for the terminology of some important normalization tables (e.g. 'Units', 'Rank\&Roles', 'Personnel flow'). In terms of language and experience with this type of sources, the Digital Framework is suitable for students and junior researchers interested in the topic, or in Digital Humanities, but with reduced paleographical skills (e.g. the 'Statistics' tables), and at the same time for experienced researchers with advanced knowledge of the sources, who can use it either for individual data storage and structuring in view of analyses, or for collaborative purposes.

The basic search engine provided by the main interface is equally useful for historical research, as well as for genealogical inquiries by general public, while registered users have access to a wider selection of search filters and content, together with the possibility of adding their own data.

Despite original hopes of delivering a tool useful for the whole Austrian Military Border, differences in typology and structure between documents issued in various areas and in different chronological moments impose further extensions, which we aim to provide in the future. In some cases, this implies only the adaptation of existing tables by adding fields which correspond to information not registered in the documents from Transylvania and the Banat, but present in other militarized border regions. In other cases, new tables will have to be created, corresponding to documents not encountered (at least until now) in our region of interest, but preserved for other areas (e.g. Ausrolirungs-Lista, Superarbitrirungs-Lista, ConsignationEntlassung, Deserteurs - all of them present for the Croatian military border). Last but 
not least, the possibility for new fields and entry forms to impose certain changes in the database's relationships cannot be overlooked.

In its current version, the database is stable and operable either by manual input of data, or by ingestion of .csv files, depending on the particularities of the sources. Basic search filters allow the user to retrieve information based on onomastic and chronological criteria. Its future depends now on the interest of the military and social historians of the $18^{\text {th }}$ and early $19^{\text {th }}$ centuries, and on their willingness to use it as a collaborative tool and not only as a data repository.

\section{Acknowledgements}

This paper has been published within the framework of the project Romanian Officers in the Habsburg Army and their Involvement in Civil Society (late 18th century to 1918). UEFISCDI PN-III-P1-1.1-ID-TE-2016-0432.

The idea of building a database for the Croatian military border was first developed by Dr. Alexander Buczynski and Dr. Vedran Klaužer within the framework of the project IP-2014-09-3675 Military Life and Warrior Images in Croatian Borderlands from the 16th Century until 1918, financed by the Croatian Science Foundation (Hrvatska zaklada za znanost), and their vision was the main inspirational beacon for the present endeavor. The authors would like to thank Dr. Buczynski and Dr. Klaužer for their generous help with the documentation on the Croatian regions of the Austrian Military Border, which was used for comparative purposes.

We are equally grateful to the personnel of the Austrian War Archives and to the members of the two Hungarian archive delegations for their support, patience and helpful suggestions in accessing the primary sources.

\section{Bibliography}

Amstadt, Jakob. Die k.k. Militaergrenze 1522-1881 (mit einer Gesamtbibliographie), vol. 1-2. Dissertation Phil. Würzburg, 1969.

Benigni von Mildenberg, Joseph Heinrich. Statistische Skizze der Siebenbürgischen Militär-Grenze. W. H. Thierrysche Buchhandlung, 1834.

Bernath, Mathias. "Die Errichtung der siebenbürgischen Militärgrenze und die Wiener Rumänenpolitik in der frühjosephinischen Zeit." Süd-ost Forschungen, vol. 19, 1960, pp. 164-192.

Bolovan, loan and Bolovan, Sorina Paula. "Granița militară austriacă și românii din Transilvania în sec. XVIII-XIX (studiu de caz: zona Năsăud)." Pe urmele trecutului. Profesorului Nicolae Edroiu la 70 de ani, edited by S. Andea, I.A. Popp. Centrul de Studii Transilvane, 2009, pp. 437-446.

Bolovan, Ioan and Crăciun, Bogdan and Covaci, Diana and Dumănescu, Luminița and Holom, Elena Crinela and Mârza, Daniela and Lumezeanu, Angela-Cristina. "Historical Population Database of Transylvania. A Database Manual." Studia Universitatis Babeș-Bolyai Digitalia, vol. 64 (LXIV), no. 1, 2019, pp. 9-84.

Buczynski, Alexander and Klaužer, Vedran. "Muster Rolls of the Croatian Military Frontier as Sources of Historical Demography." Workshop presentation: "Population 
Reconstruction", International Institute of Social History, February 2014. https://www.researchgate.net/publication/263817382 Muster Rolls of the Croati an Military Frontier as Sources of Historical Demography

Göllner, Carol. Regimentele grănicerești din Transilvania 1764-1851. Editura Militară, 1973.

Imreh, István. "Gábor Áron útban a forradalom felé." 1848. Arcok, eszmék, tettek.

(Tanulmányok). Kriterion Könyvkiadó, 1974, pp. 215-233.

Jesner, Sabine. Habsburgische Grenzraumpolitik in der Siebenbürgischen Militärgrenze (1760-1830). Verteidigungs- und Präventionsstrategien. PhD Thesis Karl-Franzens-Universität Graz, 2013.

Maior, Liviu. Românii în armata habsburgică: soldați și ofițeri uitați. Editura Enciclopedică, 2004.

Mandemakers, Kees and Lisa Dillon. "Best Practices with Large Database on Historical Populations." Historical Methods: A Journal of Quantitative and Interdisciplinary History, vol. 37, no. 1, 2004, pp. 34-38.

Milleker, Felix. Geschichte der Banater Militärgrenze (1764-1873). K. von Wittigschlager, 1925.

Popovici, Vlad. "The Establishment of the Austrian Military Border in Transylvania and its short- and medium-term effects." Povijesni Prilozi, vol. 54, 2018, pp. 292-294.

Réfi, Attila. "A genealógiai kutatás lehetöségei a bécsi Kriegsarchivban, különös tekintettel a 18-19. század fordulójának időszakára." A magyar geneológiai kutatás kézikönyve, I. köt., szerk. E. Kovács, A. Pandula, G. Vitek, Budapest, 2012. pp. 81-99.

Rothenberg, Gunther Erich. Die österreichische Militärgrenze in Kroatien 1522-1881. Herold, 1970.

Rothenberg, Gunther Erich. The Austrian Military Border in Croatia, 1522-1747. The University of Illinois Press, 1960.

Rothenberg, Gunther Erich. The Austrian Military Border in Croatia, 1740-1881. A Study of an Imperial Institution. The University of Chicago Press, 1966.

Sabău, Claudia Septimia. „Și ne-au făcut din grăniceri țărani...”: mentalități colective în satele năsăudene foste grănicerești în a doua jumătate a secolului al XIX-lea. Mega, 2015.

Schwicker, Johann Heinrich. Geschichte der österreichischen Militärgrenze, 1. Teil. K. Prochaska, 1883.

Șotropa, Valeriu. Districtul grăniceresc năsăudean și locul său în lupta pentru progres social și libertate națională a românilor din Transilvania. Dacia, 1975.

Süli, Attila. A 11. (székely) huszárezred az 1848-49-es forradalomban és szabadságharcban. Tortoma Könyvkiadó, 2019.

Tutula, Vasile. Organizarea militară a Principatului Transilvaniei în perioada 16911774. Nereamia Napocae, 2003.

Vaníček, Franz. Specialgeschichte der Militärgrenze. Aus Originalquellen und Quellenwerken geschöpft, vol. 1-4. Kaiserliche Hof- und Staatsdruckerei, 1875. von Wrede, Alphons. Geschichte der k. und k. Wehrmacht. L. W. Seidel \& Sohn, 1903. 
